\title{
Effects of level of dietary cation-anion difference and duration of prepartum feeding on performance and metabolism of dairy cows
}

\author{
C. Lopera, ${ }^{*}$ R. Zimpel, ${ }^{*}$ A. Vieira-Neto, ${ }^{*}$ F. R. Lopes, ${ }^{*}$ W. Ortiz, ${ }^{*}$ M. Poindexter, ${ }^{*}$ B. N. Faria, ${ }^{*}$ M. L. Gambarini, \\ E. Block,† C. D. Nelson, ${ }^{*}$ and J. E. P. Santos ${ }^{*} \ddagger^{1}$ \\ *Department of Animal Sciences, University of Florida, Gainesville 32611 \\ †Arm \& Hammer Animal Nutrition, Princeton, NJ 08543 \\ $\ddagger$ DH Barron Reproductive and Perinatal Biology Research Program, University of Florida, Gainesville 32611
}

\section{ABSTRACT}

The objectives were to evaluate the effects of feeding diets with 2 levels of negative dietary cation-anion differences (DCAD) during the last 42 or $21 \mathrm{~d}$ of gestation on performance and metabolism in dairy cows. The hypothesis was that extending feeding from 21 to $42 \mathrm{~d}$ and reducing the DCAD from -70 to $-180 \mathrm{mEq} /$ $\mathrm{kg}$ of dry matter (DM) would not be detrimental to performance. Holstein cows at $230 \mathrm{~d}$ of gestation were blocked by parity prepartum (48 entering their second lactation and 66 entering their third or greater lactation) and 305-d milk yield, and randomly assigned to 1 of 4 treatments arranged as a $2 \times 2$ factorial. The 2 levels of DCAD, -70 or $-180 \mathrm{mEq} / \mathrm{kg}$ of $\mathrm{DM}$, and 2 feeding durations, the last $21 \mathrm{~d}$ (short) or the last $42 \mathrm{~d}$ (long) prepartum resulted in 4 treatments, short -70 (n $=29)$, short $-180(\mathrm{n}=29)$, long $-70(\mathrm{n}=28)$ and long $-180(\mathrm{n}=28)$. Cows in the short treatments were fed a diet with DCAD of $+110 \mathrm{mEq} / \mathrm{kg}$ of $\mathrm{DM}$ from -42 to $-22 \mathrm{~d}$ relative to calving. After calving, cows were fed the same diet and production and disease incidence were evaluated for $42 \mathrm{~d}$ in milk, whereas reproduction and survival was evaluated for $305 \mathrm{~d}$ in milk. Blood was sampled pre- and postpartum for quantification of metabolites and minerals. Reducing the DCAD linearly decreased prepartum DM intake between -42 and -22 $\mathrm{d}$ relative to calving $(+110 \mathrm{mEq} / \mathrm{kg}$ of $\mathrm{DM}=11.5$ vs. $-70 \mathrm{mEq} / \mathrm{kg}$ of $\mathrm{DM}=10.7$ vs. $-180 \mathrm{mEq} / \mathrm{kg}$ of $\mathrm{DM}$ $=10.2 \pm 0.4$ ), and a more acidogenic diet in the last $21 \mathrm{~d}$ of the dry period reduced intake by $1.1 \mathrm{~kg} / \mathrm{d}(-70$ $\mathrm{mEq} / \mathrm{kg}$ of $\mathrm{DM}=10.8$ vs. $-180 \mathrm{mEq} / \mathrm{kg}$ of $\mathrm{DM}=9.7$ $\pm 0.5 \mathrm{~kg} / \mathrm{d}$ ). Cows fed the $-180 \mathrm{mEq} / \mathrm{kg}$ of $\mathrm{DM}$ diet had increased concentrations of ionized $\mathrm{Ca}$ in blood on the day of calving $(-70 \mathrm{mEq} / \mathrm{kg}$ of $\mathrm{DM}=1.063$ vs. $-180 \mathrm{mEq} / \mathrm{kg}$ of $\mathrm{DM}=1.128 \pm 0.020 \mathrm{mM}$ ). Extending

Received February 12, 2018.

Accepted April 23, 2018.

${ }^{1}$ Corresponding author: jepsantos@ufl.edu the duration of feeding the diets with negative DCAD from 21 to $42 \mathrm{~d}$ reduced gestation length by $2 \mathrm{~d}$ (short $=277.2$ vs. long $=275.3 \mathrm{~d}$ ), milk yield by $2.5 \mathrm{~kg} / \mathrm{d}$ ( short $=40.4$ vs. long $=37.9 \pm 1.0 \mathrm{~kg} / \mathrm{d}$ ) and tended to increase days open because of reduced pregnancy per artificial insemination ( short $=35.0$ vs. long $=22.6 \%$ ). Results suggest that increasing the duration of feeding diets with negative DCAD from 21 to $42 \mathrm{~d}$ prepartum might influence milk yield and reproduction of cows in the subsequent lactation, although yields of $3.5 \%$ fat- and energy-corrected milk did not differ with treatments. Reducing the DCAD from -70 to $-180 \mathrm{mEq} /$ $\mathrm{kg}$ of DM induced a more severe metabolic acidosis, increased ionized $\mathrm{Ca}$ concentrations prepartum and on the day of calving, and decreased colostrum yield in the first milking, but had no effects on performance in the subsequent lactation. Collectively, these data suggest that extending the feeding of an acidogenic diet beyond $21 \mathrm{~d}$ is unnecessary and might be detrimental to dairy cows, and a reduction in the DCAD from -70 to -180 $\mathrm{mEq} / \mathrm{kg}$ of $\mathrm{DM}$ is not needed.

Key words: acidogenic diets, dairy cow, DCAD, transition

\section{INTRODUCTION}

A large proportion of dairy cows undergo a period of disruption in Ca homeostasis with the onset of colostrogenesis and lactation. The demands for $\mathrm{Ca}$ for colostrum and milk synthesis induce a sudden drop in blood concentrations of ionized (iCa) and total $\mathrm{Ca}$ (tCa), resulting in some cows developing clinical hypocalcemia, also known as milk fever. Normal concentrations of tCa in blood usually range between 2.2 and $2.7 \mathrm{mM}$, but the onset of lactation results in sequestration of $\mathrm{Ca}$ in the mammary gland followed by loss via colostrum secretion, which can represent 7 to 10 times the estimated amount of tCa present in blood of a cow (Horst et al., 2005). The irreversible loss of tCa results in reductions in blood tCa to values lower 
than $2.2 \mathrm{mM}$ (Reinhardt et al., 2011; Martinez et al., 2012 , 2016). The inability of the cow to re-establish concentrations of $\mathrm{iCa}$ and $\mathrm{tCa}$ in blood is responsible for the development of hypocalcemia in the first days of lactation. Reinhardt et al. (2011) used the cutoff values of serum concentrations of tCa between 1.4 and $2.0 \mathrm{~m} M$ for subclinical hypocalcemia and below $1.4 \mathrm{mM}$ for clinical hypocalcemia. Using those cutoff values, the authors reported prevalence of $1 \%$ of clinical hypocalcemia and $25 \%$ subclinical hypocalcemia for primiparous cows, and $7 \%$ clinical hypocalcemia and $47 \%$ subclinical hypocalcemia for multiparous cows in the first 48 $\mathrm{h}$ of calving. Cows that develop subclinical and clinical hypocalcemia have impaired subsequent health and reproduction (Curtis et al., 1985; Martinez et al., 2012).

Strategies have been developed to minimize the risk of sudden changes in blood Ca concentrations in dairy cows. Ender et al. (1971) demonstrated that feeding prepartum diets richer in strong anions relative to strong cations increased blood concentrations of tCa and prevented clinical hypocalcemia in dairy cows. These findings eventually led to the practice of feeding acidogenic diets and introduced the concept of DCAD for formulation of diets for prepartum dairy cows. One of the effects of acidogenic diets is a reduction in DMI prepartum (Charbonneau et al., 2006; Martinez et al., 2018), and the decline seems to follow a linear relationship with the decrease in DCAD (Charbonneau et al., 2006). Although numerous experiments have documented the benefits of acidogenic diets prepartum (Block, 1984), the ideal DCAD to optimize postpartum health and performance remains unclear. Excessive feeding of acidogenic diets might influence energy metabolism and impair insulin sensitivity (Bigner et al., 1996). Despite the calculated DCAD fed, acidogenic diets will vary in DCAD in part because of the variability in mineral composition in major feedstuffs, especially forages (St-Pierre and Weiss, 2017), which seems to be common in dairy herds (Stone and Mosley, 2017).

Under some feeding management systems, providing a single diet prepartum might facilitate implementation of acidogenic diets, particularly in small dairy farms or those in which facilities are limited. Grouping cohorts of dry cows with similar calving dates in the same pen minimizes pen movements and regrouping, which minimizes changes in behavior of prepartum cows (Schirmann et al., 2011). Nevertheless, only 2 experiments have evaluated the effects of altering the duration of feeding acidogenic diets prepartum (Weich et al., 2013; Wu et al., 2014). In those experiments, cows were fed diets with -150 (Weich et al., 2013) or -200 $\mathrm{mEq} / \mathrm{kg}$ of $\mathrm{DM}$ (Wu et al., 2014) and no detrimental effects were observed on performance when feeding was extended from 21 to $42 \mathrm{~d}$ prepartum.
Most experiments have focused on the effects of feeding prepartum diets with different levels of DCAD on Ca metabolism and performance of dairy cows (Block, 1984; Leno et al., 2017), but limited research has been conducted on the effects of a prolonged duration of feeding diets with negative DCAD to transition cows. Based on the data available, we hypothesized that decreasing the negative DCAD from -70 to $-180 \mathrm{mEq} /$ $\mathrm{kg}$ of DM and extending the duration of feeding from 21 to $42 \mathrm{~d}$ would not affect performance and metabolism in dairy cows. Therefore, our objectives were to evaluate the effects of 2 durations of feeding acidogenic diets prepartum, the last 21 or $42 \mathrm{~d}$ of gestation, and at 2 levels of negative DCAD, -70 or $-180 \mathrm{mEq} / \mathrm{kg}$ of DM, on acid-base status, colostrum yield and composition, lactation performance, health, and reproduction in Holstein dairy cows.

\section{MATERIALS AND METHODS}

The University of Florida Institutional Animal Care and Use Committee approved all procedures involving cows in the experiment under protocol number 201509133.

\section{Cows and Housing}

The experiment was conducted in the University of Florida Dairy Unit (Gainesville) from November 2015 to July 2016. One hundred fourteen apparently healthy, dry Holstein cows, pregnant to AI, were enrolled in the experiment, 48 that completed the first lactation and 66 cows that completed lactation 2 or greater. Details of cows according to treatment are presented in Supplemental Table S1 (https://doi.org/10.3168/jds .2018-14580).

Pregnant, nonlactating cows at $230 \pm 3 \mathrm{~d}$ of gestation were moved to the experimental barn to acclimate to the facilities. Cows were trained for the first $2 \mathrm{~d}$ to use individual feeding gates (Calan Broadbent feeding system, American Calan Inc., Northwood, NH), and measurements started at $232 \pm 3 \mathrm{~d}$ of gestation. The last $42 \mathrm{~d}$ of gestation were used for statistical analysis of prepartum data. Cows were housed together in a freestall barn with sand-bedded stalls, and each cow was randomly assigned to a feeding gate. Immediately after calving, all postpartum cows were moved to a second pen and housed together for the first 42 DIM. The experimental pens were equipped with 2 rows of fans (1 fan/6 m) placed above the beds; a water soaker line with nozzles was placed above the feedbunk for evaporative cooling of cows. Fans and water spraying were controlled by thermostats and activated when ambient temperature reached $18^{\circ} \mathrm{C}$. 


\section{Feeding Management and Treatments}

Cows were fed once daily, at $0730 \mathrm{~h}$, prepartum and thrice daily postpartum, at approximately 0700, 1100, and $1500 \mathrm{~h}$. Individual feed intake was measured daily only during the prepartum period. Postpartum cows were fed as a group. The amounts of feed offered to individual cows prepartum were adjusted daily to result in at least $5 \%$ refusals, which were weighed once daily, before the morning feeding.

The experiment followed a randomized complete block design with cow as the experimental unit. Weekly cohorts of prepartum cows at $230 \mathrm{~d}$ of gestation were blocked by parity ( 1 vs. >1) and previous lactation 305-d milk yield and, within each block, assigned randomly to 1 of the 4 treatments. Treatments were arranged as a factorial with 2 levels of negative DCAD, -70 or $-180 \mathrm{mEq} / \mathrm{kg}$ of $\mathrm{DM}$ fed for 2 durations, the last $21 \mathrm{~d}$ of gestation, designated as the short period of feeding, or the last $42 \mathrm{~d}$ of gestation, designated as the long period of feeding; therefore, the 4 treatments were -70_short, -180_short, -70_long, and -180_long. For cows in short treatments, a diet with a positive DCAD of $+110 \mathrm{mEq} / \mathrm{kg}$ of $\mathrm{DM}$ was fed from 230 to $254 \mathrm{~d}$ of gestation. Cows assigned to the -70_short and -180_short treatments were switched to the respective negative DCAD diets, -70 and -180 $\mathrm{mEq} / \mathrm{kg}$ of DM, at $255 \mathrm{~d}$ of gestation and fed those diets until calving. Prepartum diets were formulated to be isocaloric, isonitrogenous, and have the same forage content and mineral composition, except for concentrations of strong ions to manipulate the DCAD to achieve -70 or $-180 \mathrm{mEq} / \mathrm{kg}$ of DM (Table 1 ).

\section{Ingredient Sampling, Chemical Analyses, and Calculation of DMI}

Forages and concentrate mixtures were collected weekly, dried at $55^{\circ} \mathrm{C}$ for $48 \mathrm{~h}$ with moisture loss recorded, and stored for later analyses as monthly composites. Dried samples were ground to pass a 1-mm screen of a Wiley mill (Thomas Scientific, Swedesboro, NJ), and analyzed for DM $\left(105^{\circ} \mathrm{C}\right.$ for $\left.12 \mathrm{~h}\right)$. Dried samples were composited monthly and then analyzed for ash $\left(512^{\circ} \mathrm{C}\right.$ for $8 \mathrm{~h}$ ), for NDF (sequentially using a heat-stable $\alpha$-amylase) and ADF per Van Soest et al. (1991), for $\mathrm{N}$ using an automated quantitative combustion digestion method (Leco FP628, Leco Corp. St. Joseph, MI), for starch after acid hydrolysis (Vidal et al., 2009), for total fatty acids (Sukhija and Palmquist, 1988), and for minerals by inductively-coupled plasma MS. The $\mathrm{NE}_{\mathrm{L}}$ density of the diets was calculated using chemical analyses of dietary ingredients and adjusted for 12.0 and $22.0 \mathrm{~kg}$ of DMI for the pre- and postpartum peri- ods, respectively, using the NRC (2001) model (Table 1). Prepartum intake for each cow was calculated daily for the last $42 \mathrm{~d}$ of gestation based on the weekly DM content measured at $105^{\circ} \mathrm{C}$ of the ingredients and the respective composition of diets.

\section{$B W$ and $B C S$}

Cows were weighed and body condition scored using a 1 to 5 scale (Ferguson et al., 1994) as depicted in the Elanco BCS chart (Elanco Animal Health, 2009) on the day of enrollment and then once weekly prepartum, in the morning, until calving. The same person scored all cows. Postpartum, immediately after each milking, cows were weighed on a walk-though scale (AfiWeigh, S.A.E. Afimilk, Kibbutz Afikim, Israel) and body condition was scored once weekly, as described previously.

\section{Blood Sampling and Processing}

Starting at $256 \mathrm{~d}$ of gestation, blood was sampled from all cows every other day until calving, and then on d $0,1,2,3,4,5,7,14$, and 21 postpartum by puncture of the coccygeal blood vessels into evacuated tubes (Vacutainer, Becton Dickinson, Franklin Lakes, NJ). Tubes contained either lithium heparin as an anticoagulant agent for plasma separation and subsequent analyses of tCa, total P (tP), total $\mathrm{Mg}(\mathbf{t M g})$, and glucose, or $\mathrm{K}_{2}$ EDTA as an anticoagulant for plasma separation and analyses of nonesterified fatty acids (NEFA) and BHB. Immediately upon sampling, tubes were placed in ice and transported to the laboratory within $1 \mathrm{~h}$. Cold tubes were centrifuged for $15 \mathrm{~min}$ at $2,500 \times g$ at $7^{\circ} \mathrm{C}$ for plasma separation. Plasma samples were transferred into multiple aliquots of 1.0 or $2.0 \mathrm{~mL}$ and stored frozen at $-20^{\circ} \mathrm{C}$ until analyses.

Prepartum samples collected on d $-14,-12,-10$, $-8,-6,-4$, and -2 relative to calving were assayed for concentrations of tCa, $\mathrm{tP}, \mathrm{tMg}$, glucose, NEFA, and BHB. Samples collected on d 0, 1, 2, 3, 4, 5, 7, 14, and 21 were assayed for concentrations of glucose, NEFA, and $\mathrm{BHB}$, whereas those collected on d $0,1,2,3,4,5$, and 7 were assayed for concentrations of tCa, tP, and $\mathrm{tMg}$.

\section{Sampling Whole Blood and Measurements of iCa, $\mathrm{Na}, \mathrm{K}$, and Acid-Base Status}

Whole blood was sampled by puncture of the jugular vein from all cows at $254 \mathrm{~d}$ of gestation, the day before switching cows assigned to the short treatments to their respective negative DCAD diets. Whole blood was sampled again from a subset of the first 21 blocks comprising 80 cows $\left(-70 \_s h o r t=21,-180 \_\right.$short $=$ 
20, $-70 \_$long $=19$, and $-180 \_$long $\left.=21\right)$ at 268 and postpartum. Samples were analyzed within 1 to 2 min $272 \mathrm{~d}$ of gestation, corresponding to -10 and $-6 \mathrm{~d}$ for concentrations of $\mathrm{iCa}, \mathrm{Na}, \mathrm{K}, \mathrm{pH}$, bicarbonate, base relative to expected calving, and at $0,1,2,3$, and $4 \mathrm{~d}$ excess, total dissolved $\mathrm{CO}_{2}\left(\mathbf{t} \mathbf{C O}_{2}\right)$, saturation of $\mathrm{O}_{2}$

Table 1. Ingredient composition and nutrient content of diets fed during the prepartum and postpartum periods

\begin{tabular}{|c|c|c|c|c|}
\hline Item & \multicolumn{3}{|c|}{ Prepartum diet ${ }^{1}$} & Lactation \\
\hline \multicolumn{5}{|l|}{ Ingredient, $\%$ of DM } \\
\hline Corn silage & 34.2 & 34.2 & 34.2 & 33.8 \\
\hline Triticale silage & 20.3 & 20.3 & 20.3 & - \\
\hline Bermuda hay & 6.7 & 6.7 & 6.7 & - \\
\hline Acidogenic supplement ${ }^{2}$ & - & 5.2 & 8.3 & - \\
\hline Corn grain, finely ground & - & - & - & 10.7 \\
\hline Brewer's grains, wet & - & - & - & 9.3 \\
\hline Soybean hulls & - & - & - & 4.4 \\
\hline Saturated free fatty acids ${ }^{3}$ & - & - & - & 1.7 \\
\hline Prepartum mineral-vitamin mixture ${ }^{4}$ & $\overline{4.2}$ & 4.2 & $\overline{4.2}$ & 1.1 \\
\hline $\mathrm{CP}, \%$ & $14.9 \pm 0.8$ & $14.7 \pm 0.4$ & $14.6 \pm 0.6$ & $17.4 \pm 0.5$ \\
\hline $\mathrm{ADF}, \%$ & $29.4 \pm 1.4$ & $28.9 \pm 1.2$ & $29.1 \pm 1.1$ & $22.5 \pm 2.4$ \\
\hline NDF, $\%$ & $43.1 \pm 1.7$ & $43.7 \pm 1.5$ & $43.8 \pm 1.5$ & $31.6 \pm 1.9$ \\
\hline Forage NDF, \% & $39.3 \pm 1.7$ & $39.3 \pm 1.7$ & $39.3 \pm 1.7$ & $20.0 \pm 1.6$ \\
\hline $\mathrm{NFC}^{9} \%$ & $31.7 \pm 1.3$ & $31.1 \pm 1.6$ & $31.1 \pm 1.9$ & $37.3 \pm 3.3$ \\
\hline Starch, \% & $12.3 \pm 0.4$ & $12.6 \pm 0.5$ & $12.9 \pm 0.6$ & $20.5 \pm 2.6$ \\
\hline Fatty acids, $\%$ & $2.8 \pm 0.2$ & $2.8 \pm 0.1$ & $2.8 \pm 0.1$ & $4.0 \pm 0.1$ \\
\hline $\mathrm{Ca}, \%$ & $0.67 \pm 0.07$ & $0.64 \pm 0.05$ & $0.62 \pm 0.05$ & $1.00 \pm 0.38$ \\
\hline $\mathrm{P}, \%$ & $0.33 \pm 0.01$ & $0.33 \pm 0.02$ & $0.33 \pm 0.03$ & $0.38 \pm 0.02$ \\
\hline $\mathrm{Mg}, \%$ & $0.44 \pm 0.06$ & $0.47 \pm 0.06$ & $0.48 \pm 0.03$ & $0.40 \pm 0.03$ \\
\hline $\mathrm{K}, \%$ & $1.54 \pm 0.10$ & $1.49 \pm 0.09$ & $1.46 \pm 0.09$ & $1.65 \pm 0.09$ \\
\hline S, $\%$ & $0.29 \pm 0.03$ & $0.40 \pm 0.03$ & $0.47 \pm 0.03$ & $0.21 \pm 0.01$ \\
\hline $\mathrm{Na}, \%$ & $0.08 \pm 0.03$ & $0.11 \pm 0.03$ & $0.13 \pm 0.04$ & $0.55 \pm 0.03$ \\
\hline $\mathrm{Cl}, \%$ & $0.50 \pm 0.07$ & $0.86 \pm 0.07$ & $1.11 \pm 0.03$ & $0.66 \pm 0.05$ \\
\hline
\end{tabular}

${ }^{1}$ Cows were fed the following diets according to treatment: $-70 \_$short $=$diet containing $+110 \mathrm{mEq} / \mathrm{kg}$ of DM from 232 to $254 \mathrm{~d}$ of gestation, followed by a diet with $-70 \mathrm{mEq} / \mathrm{kg}$ of DM from $255 \mathrm{~d}$ of gestation to calving; -180 short = diet containing $+110 \mathrm{mEq} / \mathrm{kg}$ of DM from $232 \mathrm{to}$ $254 \mathrm{~d}$ of gestation, followed by a diet with $-180 \mathrm{mEq} / \mathrm{kg}$ of DM from $255 \mathrm{~d}$ of gestation to calving; $-70 \_$long $=$diet containing $-70 \mathrm{mEq} / \mathrm{kg}$ of DM from $232 \mathrm{~d}$ of gestation to calving; -180_long = diet containing $-180 \mathrm{mEq} / \mathrm{kg}$ of DM from $232 \mathrm{~d}$ of gestation to calving.

${ }^{2}$ Bio-Chlor (fermentation product containing dried condensed extracted glutamic acid fermentation product, dried condensed corn fermentation solubles, processed grain by-products, and magnesium chloride; Arm \& Hammer Animal Nutrition, Princeton, NJ).

${ }^{3}$ Energy-Booster Mag (fat supplement containing 95.8\% fatty acids and 2.3\% Mg, Milk Specialties Global, Eden Prairie, MN).

${ }^{4}$ Contains (DM basis) 3.7\% Ca, 0.9\% P, $5.5 \% \mathrm{Mg}, 0.9 \% \mathrm{~K}, 2.3 \% \mathrm{~S}, 1.1 \% \mathrm{Na}, 1.6 \% \mathrm{Cl}$, and per $\mathrm{kg}$ of DM, $724 \mathrm{mg}$ of $\mathrm{Zn}, 165 \mathrm{mg}$ of $\mathrm{Cu}, 543 \mathrm{mg}$ of Mn, $9 \mathrm{mg}$ of Se, $16 \mathrm{mg}$ of I, $4 \mathrm{mg}$ of Co, 232,000 IU of vitamin A, 67,000 IU of vitamin $\mathrm{D}_{3}, 3,300 \mathrm{IU}$ of vitamin E, $750 \mathrm{mg}$ of monensin, and $54 \mathrm{~g}$ of choline ion in a rumen-protected form.

${ }^{5}$ A mixture containing $20 \%$ blood meal enriched with rumen-protected lysine and methionine (LysAAMet, Perdue Ag Solutions LLC, Salisbury, MD). Contains (DM basis) 19.1\% CP, $6.3 \% \mathrm{Ca}, 2.0 \% \mathrm{P}, 3.4 \% \mathrm{Mg}, 8.3 \% \mathrm{~K}, 0.3 \% \mathrm{~S}, 9.3 \% \mathrm{Na}, 5.3 \% \mathrm{Cl}$, and per kg of DM, $500 \mathrm{mg}$ of $\mathrm{Zn}, 115 \mathrm{mg}$ of $\mathrm{Cu}, 421 \mathrm{mg}$ of Mn, $6.4 \mathrm{mg}$ of Se, $11.1 \mathrm{mg}$ of I, $3.9 \mathrm{mg}$ of Co, 110,000 IU of vitamin A, 27,000 IU of vitamin $\mathrm{D}_{3}, 1,300 \mathrm{IU}$ of vitamin E, 380 mg of monensin (Rumensin 90, Elanco Animal Health, Eli Lilly and Co, Indianapolis, IN), $22 \mathrm{mg}$ of biotin, and $16 \mathrm{~g}$ of choline ion in a rumenprotected form (Reashure, Balchem Co., New Hampton, NY).

${ }^{6}$ Novasil Plus (BASF Corp., Florham Park, NJ).

${ }^{7}$ Samples of ingredients were collected weekly and composited each month for chemical analyses. A total of 5 samples of each ingredient was analyzed for chemical composition.

${ }^{8}$ Estimated using NRC (2001) according to chemical analyses of dietary ingredients and adjusted for DMI of $12 \mathrm{~kg} / \mathrm{d}$ prepartum and $22 \mathrm{~kg} / \mathrm{d}$ postpartum.

${ }^{9} \mathrm{OM}-(\mathrm{CP}+$ fatty acids $+\mathrm{NDF})$.

${ }^{10}$ Calculated as $[(\mathrm{mEq}$ of $\mathrm{K})+(\mathrm{mEq}$ of $\mathrm{Na})]-[(\mathrm{mEq}$ of $\mathrm{Cl})+(\mathrm{mEq}$ of $\mathrm{S})]$. 
$\left(\mathrm{sO}_{2}\right)$, and partial pressures of $\mathrm{O}_{2}$ and $\mathrm{CO}_{2}\left(\mathbf{p C O}_{2}\right)$ using a hand-held biochemical analyzer (VetScan i-STAT, Abaxis, Union City, CA).

\section{Blood Assays}

All assays followed the initial randomization with blocks, such that samples from each block were analyzed in the same assay. Plasma concentrations of NEFA (NEFA-C kit; Wako Diagnostics Inc., Richmond, VA; according to Johnson and Peters, 1993) and BHB (Wako Autokit 3-HB; Wako Diagnostics, Inc.) were analyzed using colorimetric enzymatic assays. The intra- and interassay coefficients of variation $(\mathbf{C V})$ were, respectively, 3.4 and $8.4 \%$ for NEFA and 1.0 and $4.0 \%$ for BHB. Concentrations of glucose in plasma were determined by colorimetric continuous flow analysis (Autoanalyzer II, Seal Analytical, Southampton, UK) using a modification of the method described by Gochman and Schmitz (1972). Plasma concentrations of tCa and $\mathrm{tMg}$ were analyzed by atomic absorption using a spectrophotometer equipped with $\mathrm{Ca}$ - and $\mathrm{Mg}$-specific hollow cathode lamps (AAnalyst 200, Perkin-Elmer Inc., Waltham, MA) as described by Martinez et al. (2012). Intra- and interassay CV were, respectively, 1.8 and $5.1 \%$ for tCa and 1.6 and $4.4 \%$ for tMg. Concentrations of tP were quantified in plasma using the molybdenum blue method (Quinlan and DeSesa, 1955). The intra- and interassay CV were, respectively, 3.4 and $10.1 \%$.

\section{Urine Collection and Analysis}

Urine was sampled twice weekly prepartum, on Wednesdays and Saturdays, by manually stimulating the perineal area until obtaining a clean and copious stream. Approximately $50 \mathrm{~mL}$ was sampled, placed in ice, and had $\mathrm{pH}$ measured within $10 \mathrm{~min}$ of collection using a pH meter (Accumet AR15 pH meter, Fisher Scientific International Inc., Hampton, NH). Samples collected in the last 2 wk of gestation were composited by week, and each composite sample was split into multiple aliquots and stored at $-20^{\circ} \mathrm{C}$ until analyses. Concentrations of $\mathrm{tCa}, \mathrm{tMg}$, and creatinine were analyzed in duplicate for each sample using the colorimetric methods in a biochemical analyzer (kits no. CA3871, MG3880, and CR3814, Randox Laboratories Ltd., Crumlin, UK). The intra- and interassay CV were, respectively, 3.2 and $1.4 \%$ for tCa, 2.5 and $4.5 \%$ for $\mathrm{tMg}$, and 3.3 and $5.8 \%$ for creatinine. All assays followed the initial randomization with blocks such that samples from each block were analyzed in the same assay. Creatinine was used as a marker to estimate daily urinary volume based on the constant excretion of $29 \mathrm{mg}$ of creatinine $/ \mathrm{kg}$ of BW per day as urinary volume $=\mathrm{BW} \times 29 /$ creatinine concentration $(\mathrm{mg} / \mathrm{L})$ (Valadares et al., 1999). The estimate of daily urinary volume was calculated using the mean BW of each cow in the week the urine sample was taken. Daily urinary excretions of tCa and tMg were calculated as the product of urinary volume and the respective concentrations of those minerals in the urine samples.

\section{Measurement and Analysis of Colostrum}

Cows were milked for the first time within the first $6 \mathrm{~h}$ after calving and colostrum yield was measured and recorded for the first and second milkings (AfiFlo; S.A.E. Afikim, Israel). The second postpartum milking occurred $6 \mathrm{~h}$ later and yield of colostrum or transition milk was also measured. Duplicate samples were collected during the first and second milkings and each sample was diluted 1:1 with skim milk. Samples of skim milk and diluted colostrum samples were analyzed in duplicates for concentrations of fat, true protein, lactose, SNF, TS, and SCC at the DHI Southeast Milk laboratory in Belleview, Florida. Concentrations in the original colostrum samples were then back calculated. Concentrations of $\mathrm{tCa}$ and $\mathrm{tMg}$ in first and second milking colostrum were analyzed by atomic absorption as described by Vieira-Neto et al. (2017b). Intra- and interassay CV were, respectively, 0.9 and $1.4 \%$ for tCa and 0.3 and $0.5 \%$ for $\mathrm{tMg}$.

A sample of colostrum from first milking was frozen for subsequent analysis of concentration of IgG by radial immunodiffusion assay (Triple J Farms, Bellingham, WA) per the manufacturer's protocol (https:// kentlabs.com/jjj/product/bovine-igg-test-kit-radial -immunodiffusion-test-kit/). Briefly, colostrum was diluted $1: 5$ in $0.9 \%$ saline such that the concentration of IgG would fall within the linear range of the standard curve of the assay. The diluted samples were pipetted in duplicates into the bovine anti-bovine IgG antibody plate and incubated for $27 \mathrm{~h}$ on a flat surface protected from light. The diameter of the precipitin ring was measured using a $7 \times$ scale loupe (no. 1975, Peak Optics, GWJ Company, La Quinta, CA) and used to calculate the IgG concentrations; intra- and interassay CV were, respectively, 1.8 and $2.3 \%$.

\section{Measurements of Yields of Milk and Milk Components}

Cows were milked twice daily, at 0600 and $1800 \mathrm{~h}$, and yields of milk were recorded automatically (AfiFlo milk meters, Afimilk) for the first 42 DIM. Samples of milk were collected from 2 consecutive milkings, morning and afternoon, every Monday and Wednesday for 
analyses of concentrations of fat, true protein, lactose, and SCC at the DHI Southeast Milk laboratory (Belleview, FL). Milk yield from each sampling milking was used to calculate the final concentrations of milk components. For calculation of yields and content of milk components, $3.5 \%$ FCM, and ECM, the samples collected on Mondays represented the concentrations of milk components on Saturday, Sunday, and Monday, whereas the samples collected on Wednesday represented the concentrations on Tuesday, Wednesday, Thursday, and Friday of each week. Yields of milk corrected for $3.5 \%$ fat content and for energy and the NE content of milk were calculated as $3.5 \%$ FCM $(\mathrm{kg} / \mathrm{d})=0.4324$ $\times$ milk $(\mathrm{kg})+[16.218 \times$ milk fat $(\mathrm{kg})] ; \mathrm{ECM}(\mathrm{kg} / \mathrm{d})$ $=(0.3246 \times$ milk yield $)+(12.86 \times$ fat yield $)+(7.04$ $\times$ protein yield $) ; \mathrm{NE}_{\mathrm{L}}(\mathrm{Mcal} / \mathrm{kg})=(0.0929 \times$ fat $\%)+$ $(0.0563 \times$ protein $\%)+(0.0395 \times$ lactose $\%)$.

\section{Measurement of Net Energy Balance Prepartum}

Energy balance was calculated using the NE system according to NRC (2001). The needs for maintenance were calculated based on metabolic BW $\left(0.08 \times \mathrm{BW}^{0.75}\right)$. Net energy of lactation for pregnancy was calculated at $3.7 \mathrm{Mcal} / \mathrm{d}$, considering a newborn calf weighing $43 \mathrm{~kg}$. Net energy intake was calculated based on the $\mathrm{NE}_{\mathrm{L}}$ content of the diets multiplied by each cow's DMI.

\section{Characterization and Diagnosis of Health Problems}

Milk fever was characterized by a down cow that responded to intravenous administration of a solution containing $10.8 \mathrm{~g}$ of $\mathrm{Ca}$ as Ca borogluconate (Cal-Dex CMPK injection, Agrilabs, St. Joseph, MO). A blood sample was collected immediately before treatment to confirm the diagnosis by measuring the concentration of iCa. Retained placenta was characterized by the retention of fetal membranes $12 \mathrm{~h}$ after calving. Metritis was evaluated by transrectal palpation on $\mathrm{d} 4,7$, and 12 postpartum and characterized by an enlarged uterus with fetid watery discharge. Rectal temperature of all cows was measured on d 4, 7, and 12 postpartum, and those with temperatures greater than $39.5^{\circ} \mathrm{C}$ were classified as having fever. Cows with fever concurrent with metritis were classified as having puerperal metritis. At every milking, cows were examined for signs of clinical mastitis by the herd personnel immediately before milking based on presence of abnormal milk in one or more quarters. Displaced abomasum was diagnosed by percussion and auscultation of the flanks and confirmed during surgical intervention for correction by omentopexy. Cows with more than 1 clinical disease event were classified as having multiple diseases. Mor- bidity included milk fever, retained placenta, metritis, mastitis, or displaced abomasum recorded from calving to 42 DIM. Removal from the herd was determined for the first 305 DIM.

Subclinical hypocalcemia was analyzed considering 3 distinct thresholds: whole blood iCa $\leq 1.0 \mathrm{mM}$ (Oetzel, 1988), plasma tCa $\leq 2.0 \mathrm{~m} M$ (Reinhardt et al., 2011), or plasma tCa $<2.15 \mathrm{mM}$ (Martinez et al., 2012). Incidence of subclinical hypocalcemia was based on at least 1 sample with concentration below the respective threshold on d $0,1,2,3$, or 4 postpartum. Daily prevalence was calculated using the same thresholds from 0 to $4 \mathrm{~d}$ postpartum.

\section{Reproductive Management and Reproductive Responses}

All cows were subjected to the double Ovsynch protocol for first AI (Souza et al., 2008). Briefly, cows received an i.m. injection of $100 \mu \mathrm{g}$ of $\mathrm{GnRH}$ (Cystorelin, $50 \mu \mathrm{g} / \mathrm{mL}$ of gonadorelin diacetate tetrahydrate, Merial, Duluth, GA) at $53 \pm 3 \mathrm{DIM}$, followed by an i.m. injection of $25 \mathrm{mg}$ of $\mathrm{PGF}_{2 \alpha}$ (Lutalyse Sterile Solution, $5 \mathrm{mg} / \mathrm{mL}$ of dinoprost as tromethamine salt; Zoetis, Florham Park, NJ) at $60 \pm 3$ DIM and another injection of $100 \mu \mathrm{g}$ of $\mathrm{GnRH}$ at $63 \pm 3$ DIM. Seven days later, at $70 \pm 3$ DIM, the same sequence of injections was repeated with the final $\mathrm{GnRH}$ administered in the afternoon of d $79 \pm 3$ postpartum, and timed AI was performed in the morning of d $80 \pm 3$ postpartum, approximately 14 to $16 \mathrm{~h}$ after the last GnRH treatment.

Pregnancy was diagnosed by transrectal ultrasonography on d 32 after each AI based on the presence of an amniotic vesicle with an embryo with heartbeat. Nonpregnant cows had the estrous cycle resynchronized for timed AI with the Ovsynch protocol to be reinseminated $10 \mathrm{~d}$ after the nonpregnancy diagnosis. Pregnant cows on d 32 were re-evaluated for pregnancy $35 \mathrm{~d}$ later, at $67 \mathrm{~d}$ after AI. For statistical analyses, the diagnosis on d 67 after AI was used to determine if a cow became pregnant to the first or subsequent AI. Interval to pregnancy up to $305 \mathrm{~d}$ postpartum was recorded. Cows that became "do not inseminate," were sold or died, or remained nonpregnant by $305 \mathrm{~d}$ postpartum were censored on the respective dates. Responses measured included proportion of cows receiving AI, days postpartum at first AI, pregnancy per $\mathrm{AI}(\mathbf{P} / \mathbf{A I})$ at first $\mathrm{AI}, \mathrm{P} / \mathrm{AI}$ at all $\mathrm{AI}$, and interval to pregnancy.

\section{Statistical Analysis}

The experiment followed a randomized complete block design with a $2 \times 2$ factorial arrangement of 
treatments with 2 durations of feeding ( 21 vs. 42 d) and 2 levels of negative DCAD ( -70 vs. $-180 \mathrm{mEq} / \mathrm{kg}$ of DM) and cow as the experimental unit. Prepartum cows at $230 \pm 3 \mathrm{~d}$ of gestation were blocked by parity (lactation 1 vs. lactation >1) and previous lactation 305-d milk yield and, within each block, assigned randomly to 1 of the 4 treatments.

Normality of residuals and homogeneity of variance were examined for each continuous dependent variable analyzed after fitting the final model. Responses that violated the assumptions of normality were subjected to power transformation according to the Box-Cox procedure (Box and Cox, 1964) using the TRANSREG procedure of SAS (SAS ver. 9.4, SAS/STAT, SAS Institute Inc., Cary, NC). The variables transformed were prepartum blood BHB transformed to the inverse, and postpartum blood NEFA, BHB, and glucose transformed to the logarithm. The least squares means and standard errors of the means were back transformed for presentation of results according to Jørgensen and Pedersen (1998).

During the prepartum period, 2 statistical models were built, one for $\mathrm{d}-42$ to -22 relative to calving and another for $\mathrm{d}-21$ to -1 relative to calving. This was done because, from 232 to $254 \mathrm{~d}$ of gestation, cows assigned to the short treatments were fed a diet with $+110 \mathrm{mEq} / \mathrm{kg}$ of DM based on the design of the experiment.

Data from -42 to -22 d relative to calving were analyzed by ANOVA with the MIXED procedure of SAS (SAS/STAT). The statistical models included the fixed effects of level of DCAD (+110 vs. -70 vs. -180 $\mathrm{mEq} / \mathrm{kg}$ of DM), day of measurement, the interaction between treatment and day, parity group (primiparous vs. multiparous), and calf sex (female vs. male vs. twin), the random effects of block, and cow nested within treatment. Data with a single measurement per cow were analyzed with the fixed effects of treatment, parity group, and calf sex and the random effect of block. Orthogonal polynomial contrasts were used to determine linear and quadratic effects of DCAD. Data collected in the last $21 \mathrm{~d}$ of gestation were analyzed by ANOVA with the MIXED procedure of SAS (SAS/ STAT). The statistical models included the fixed effects of duration of feeding ( 21 vs. $42 \mathrm{~d}$ ), level of DCAD ( -70 vs. $-180 \mathrm{mEq} / \mathrm{kg}$ of $\mathrm{DM})$, day of measurement, parity group (primiparous vs. multiparous), calf sex (female vs. male vs. twin), the interactions between duration and DCAD, duration and day, DCAD and day, and duration and DCAD and day, and the random effects of block and cow nested within duration and DCAD.

Postpartum data were analyzed separately from prepartum data. Continuous variables were analyzed by ANOVA with the MIXED procedure of SAS (SAS/ STAT). The statistical models included the fixed effects of duration of feeding (21 vs. 42 d), level of DCAD ( -70 vs. $-180 \mathrm{mEq} / \mathrm{kg}$ of $\mathrm{DM})$, day of measurement, parity group (primiparous vs. multiparous), calf sex (female vs. male vs. twin), the interactions between duration and DCAD, duration and day, DCAD and day, and duration and DCAD and day, and the random effects of block and cow nested within duration and DCAD. For yields of milk and milk components, the previous lactation yield was used as covariate. Colostrum composition and changes in BW and BCS were analyzed with models that included the fixed effects of duration of feeding, level of DCAD, parity group, calf sex, the interactions between duration and DCAD, and the random effect of block.

For all mixed models with continuous data, the Kenward-Roger method was used to approximate the denominator degrees of freedom for the $F$ tests in the statistical models. Model fit was assessed based on the smallest corrected Akaike's information criterion. For repeated measures, the covariance structure was selected for each model based on spacing of measurements and the smallest corrected Akaike's information criterion. When an interaction was significant, pairwise comparisons were performed with the adjustment by Tukey.

Binary data were analyzed by logistic regression with the GLIMMIX procedure of SAS (SAS/STAT). The statistical models included the fixed effects of duration of feeding, level of DCAD, interaction between duration and DCAD, parity group, and calf sex, and the random effect of block. Binary data with repeated measures within cow, such as daily prevalence of subclinical hypocalcemia and hyperketonemia, the statistical models included the fixed effects of duration of feeding, level of DCAD, day, parity group, calf sex, and interaction between duration and DCAD, duration and day, DCAD and day, and duration and DCAD and day, and the random effects of block and cow nested within duration and DCAD.

Days to pregnancy or leaving the herd was analyzed with the Cox's proportional hazard regression using the PHREG procedure of SAS (SAS/STAT). The model included the effects of duration of feeding, level of DCAD, and interaction between duration and DCAD, parity group, and calf sex. When the interaction between duration and DCAD was nonsignificant $(P>0.10)$, it was dropped from the final model. The adjusted hazard ratio and the $95 \%$ confidence interval were calculated. The LIFETEST procedure of SAS (SAS/STAT) was used to generate the survival curves and compute the least squares means \pm standard error of the means and 
median days to event. Statistical significance was considered at $P \leq 0.05$, and tendency was considered at $0.05<P \leq 0.10$.

\section{RESULTS}

All 114 cows enrolled in the experiment were included in all statistical analyses, unless the cow died before 42 d postpartum, in which case she contributed data until the day of death. One cow fed -180_long developed obturator nerve paralysis the day after delivery because of difficult calving; thus, health data for this cow included only diagnosis of retained placenta and milk fever and she was excluded from all other postpartum analyses. Number of days dry and days prepartum on the experiment did not differ among treatments (Supplemental Table S1; https://doi.org/10.3168/jds.2018-14580). Gestation length was $2 \mathrm{~d}$ shorter $(P=0.03)$ for cows fed the long compared with the short treatments, but no effect $(P=0.15)$ of DCAD or interaction between duration and DCAD $(P=0.68)$ was detected. As designed, cows fed the short treatments received the diets with negative DCAD for approximately $21 \mathrm{~d}$, whereas those fed the long treatments received the diets with negative DCAD for a mean of $43 \mathrm{~d}$.

\section{Intake, Measures of Energy Status, and Acid-Base Balance in the Early Dry Period}

From d -42 to -22 relative to calving, cows enrolled in the short treatments were fed a diet with $+110 \mathrm{mEq} /$ $\mathrm{kg}$ of DM and data were analyzed with 3 DCAD treatments, $+110,-70$, and $-180 \mathrm{mEq} / \mathrm{kg}$ of $\mathrm{DM}$; results herein are presented in the same sequence. Reducing the DCAD from +110 to $-180 \mathrm{mEq} / \mathrm{kg}$ of DM linearly reduced $(P=0.02)$ DMI $(11.5 \pm 0.3$ vs. $10.7 \pm 0.4$ vs. $10.2 \pm 0.4 \mathrm{~kg} / \mathrm{d}$ ), which, consequently, had a linear effect in reducing $(P<0.02)$ caloric intake $(16.7 \pm$ 0.5 vs. $15.5 \pm 0.6$ vs. $14.8 \pm 0.7 \mathrm{Mcal}$ of $\mathrm{NE}_{\mathrm{L}} / \mathrm{d}$ ) and $\mathrm{NE}$ balance $(1.2 \pm 0.5$ vs. $-0.1 \pm 0.6$ vs. $-0.5 \pm 0.7$ $\mathrm{Mcal} / \mathrm{d})$. An interaction $(P=0.008)$ between treatment and day was detected because the differences in DMI increased with days in the experiment (Figure 1A). The mean BW and BCS did not differ among treatments (Supplemental Table S2; https://doi.org/ 10.3168/jds.2018-14580). Blood pH did not differ with treatment, although blood of cows showed typical signs of a compensated metabolic acidosis with linear reductions in $\mathrm{tCO}_{2}(27.8 \pm 0.6$ vs. $27.7 \pm 0.8$ vs. $24.6 \pm 0.8$ $\mathrm{m} M), \mathrm{pCO}_{2}(40.6 \pm 1.0$ vs. $43.4 \pm 1.4$ vs. $38.2 \pm 1.4$ $\mathrm{m} M)$, bicarbonate $(26.6 \pm 0.6$ vs. $26.4 \pm 0.8$ vs. $23.6 \pm$ $0.8 \mathrm{mM})$, base excess $(2.12 \pm 0.69$ vs. $1.59 \pm 0.95$ vs. $-1.17 \pm 0.94 \mathrm{mM})$, and urine $\mathrm{pH}(8.05 \pm 0.06$ vs. 6.52 \pm 0.07 vs. $5.48 \pm 0.08)$. Urinary $\mathrm{pH}$ remained relatively constant according to treatment throughout the first 21 $\mathrm{d}$ in the experiment (Figure 1C). Blood concentrations of iCa, Na, K, and glucose did not differ with treatment (Supplemental Table S2).

\section{Intake and Measures of Energy Status in the Late Dry Period}

Duration of feeding did not affect DMI in the last $21 \mathrm{~d}$ of gestation; however, reducing the DCAD from -70 to $-180 \mathrm{mEq} / \mathrm{kg}$ of $\mathrm{DM}$ reduced $(P=0.005) \mathrm{DMI}$ by $1.1 \mathrm{~kg} / \mathrm{d}(-70=10.8$ vs. $-180=9.7 \pm 0.4 \mathrm{~kg} / \mathrm{d}$; Supplemental Table S3, https://doi.org/10.3168/jds $.2018-14580)$, and the reduction was observed in cows fed short or long throughout the 21-d period (Figure 1B). The reduction in DMI resulted in less $(P=0.007)$ caloric intake in cows fed -180 rather than $-70 \mathrm{mEq} /$ $\mathrm{kg}$ of $\mathrm{DM}(15.6$ vs. $13.9 \pm 0.5 \mathrm{Mcal} / \mathrm{d})$ as well as smaller $(P=0.007) \mathrm{NE}$ balance $(-0.3$ vs. $-2.0 \pm 0.6$ $\mathrm{Mcal} / \mathrm{d})$. An interaction $(P=0.03)$ between duration of feeding and DCAD was detected for BW in part because cows fed -180_short were heavier than cows fed $-180 \_$long $\left(-70 \_\right.$short $=754$ vs. $-180 \_$short $=$ 781 vs. $-70 \_$long $=772$ vs. $-180 \_$long $=748 \pm 14$ $\mathrm{kg})$. Also, an interaction $(P=0.01)$ between duration of feeding and DCAD was observed for BW change because cows fed -70_short gained more weight than cows fed $-180 \_$short or $-70 \_$long $\left(-70 \_\right.$short $=1.0$ vs. $-180 \_$short $=0.4$ vs. $-70 \_$long $=0.5$ vs. $-180 \_$long $=0.7 \pm 0.2 \mathrm{~kg} / \mathrm{d})$. The BCS did not differ with treatment, but the change from week -6 to -1 tended $(P=$ $0.06)$ to differ with DCAD because cows fed $-70 \mathrm{mEq} /$ $\mathrm{kg}$ of DM lost less body condition than cows fed -180 $\mathrm{mEq} / \mathrm{kg}$ of $\mathrm{DM}(-0.10$ vs. $-0.20 \pm 0.05)$.

\section{Acid-Base Balance and Urinary Excretion of Minerals Prepartum}

Reducing the DCAD from -70 to $-180 \mathrm{mEq} / \mathrm{kg}$ of DM in the last $21 \mathrm{~d}$ of gestation reduced $(P<0.001)$ blood $\mathrm{pH}, \mathrm{tCO}_{2}$, bicarbonate, and base excess (Table 2). Duration of feeding acidogenic diets did not influence acid-base balance. An interaction between duration and DCAD tended $(P=0.07)$ to affect $\mathrm{pCO}_{2}$, and the value was smallest in cows fed $-180 \_$short.

Duration of feeding acidogenic diets prepartum did not influence urinary $\mathrm{pH}$, volume, concentrations of $\mathrm{Ca}$ or $\mathrm{Mg}$, and excretions of $\mathrm{Ca}$ and $\mathrm{Mg}$ (Table 2). On the other hand, reducing the DCAD from -70 to -180 $\mathrm{mEq} / \mathrm{kg}$ of $\mathrm{DM}$ decreased $(P<0.001)$ urinary $\mathrm{pH}$, but increased $(P<0.01)$ urinary volume and concentration and excretion of $\mathrm{Ca}$ in urine. Concentration of $\mathrm{Mg}$ in urine tended $(P=0.07)$ to be greater for cows fed -70 than $-180 \mathrm{mEq} / \mathrm{kg}$ of $\mathrm{DM}$, but urinary excretion did 

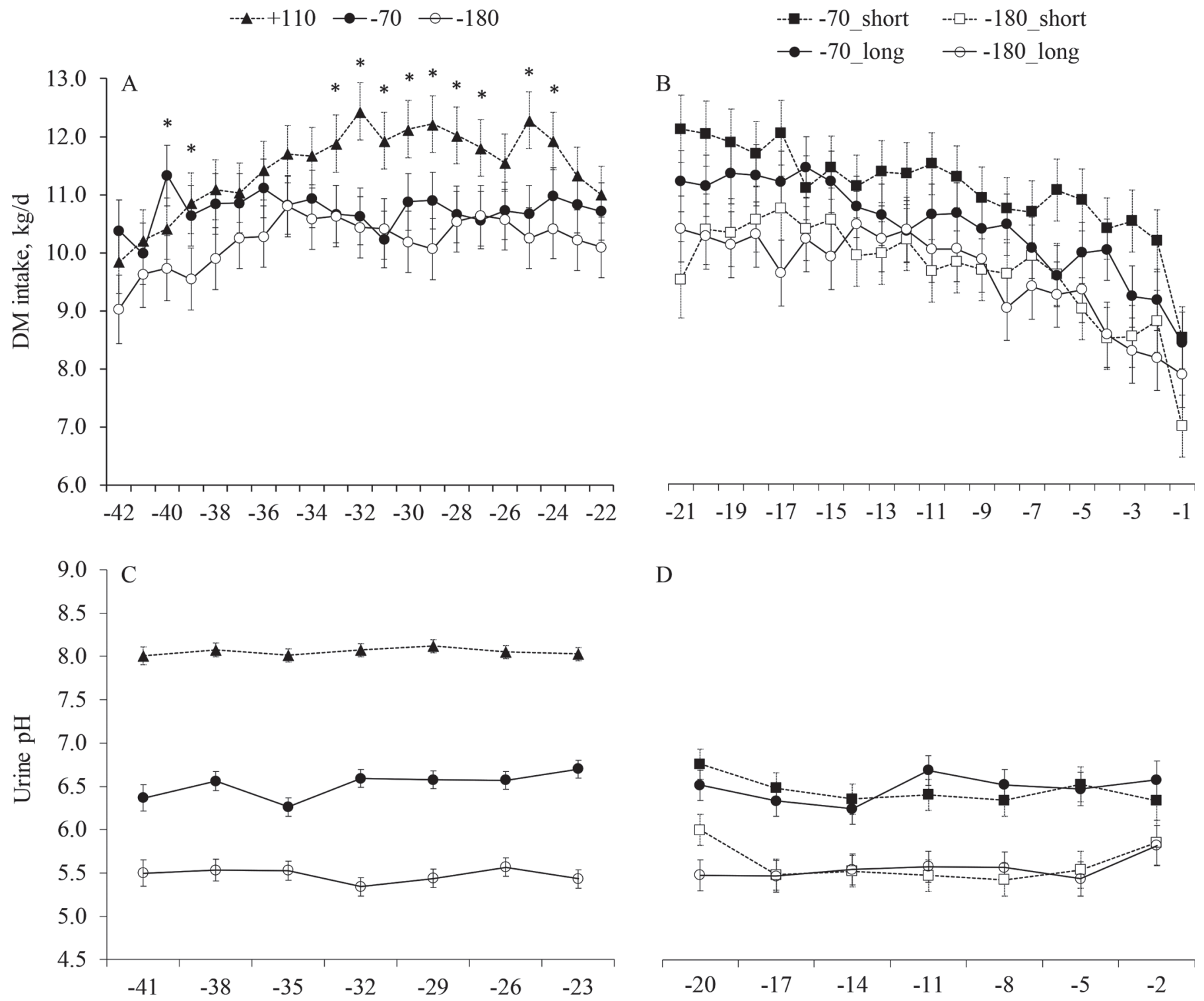

$\mathrm{D}$

\section{Day prepartum}

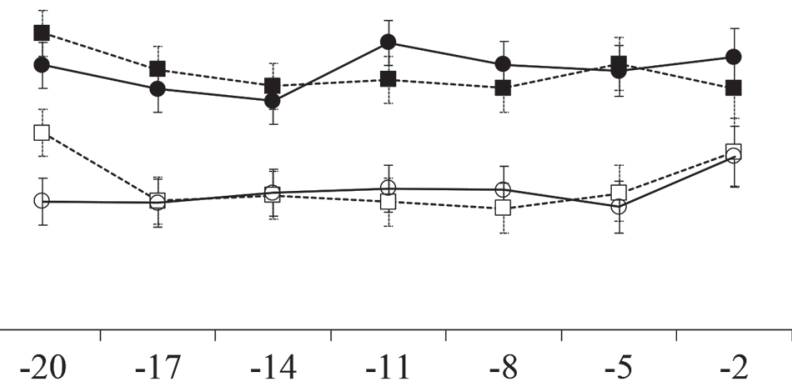

Day prepartum

Figure 1. Prepartum DMI and urine pH. (A) Dry matter intake from d -42 to -22 relative to calving when cows were fed diets with +110 , -70 , or $-180 \mathrm{mEq} / \mathrm{kg}$ of DM; (B) DMI from d -21 to -1 relative to calving according to duration of feeding (Short, $21 \mathrm{~d}$; Long, $42 \mathrm{~d}$ ) and level of DCAD ( -70 vs. $-180 \mathrm{mEq} / \mathrm{kg}$ of $\mathrm{DM}$ ); (C) urine $\mathrm{pH}$ from d -42 to -22 relative to calving when cows were fed diets with +110 , -70 , or $-180 \mathrm{mEq} / \mathrm{kg}$ of $\mathrm{DM}$; and (D) urine $\mathrm{pH}$ from d -21 to -1 relative to calving according to duration of feeding (Short, $21 \mathrm{~d}$; Long, $42 \mathrm{~d}$ ) and level of DCAD ( -70 vs. $-180 \mathrm{mEq} / \mathrm{kg}$ of DM). In (A) LSM and SEM were $+110=11.5 \pm 0.3 ;-70=10.7 \pm 0.4 ;$ and $-180=10.2 \pm 0.4 \mathrm{~kg} / \mathrm{d}$; linear effect of level of DCAD $(P=0.02)$ and interaction between level of DCAD and day $(P=0.008)$. In (B) LSM and SEM were -70_short $=11.1 \pm 0.5 ;-180 \_$short $=9.7 \pm 0.5 ;-70 \_$long $=10.5 \pm 0.5 ;$ and $-180 \_$long $=9.6 \pm 0.5 \mathrm{~kg} / \mathrm{d}$; effects of duration of feeding $(P=0.38)$, level of DCAD $(P=0.005)$, and interactions between duration and DCAD $(P=0.45)$, duration and day $(P=0.15)$ and DCAD and day $(P=$ $0.008)$. In (C) LSM and SEM were $+110=8.05 \pm 0.06 ;-70=6.52 \pm 0.07$; and $-180=5.48 \pm 0.08$; linear effect of level of DCAD $(P<0.001)$ and interaction between level of DCAD and day $(P=0.11)$. In $(\mathrm{D})$ LSM and SEM were $-70 \_$short $=6.46 \pm 0.14 ;-180 \_$short $=5.62 \pm 0.14$; $-70 \_$long $=6.48 \pm 0.14 ;$ and $-180 \_$long $=5.56 \pm 0.14$; effects of duration of feeding $(P=0.81)$, level of DCAD $(P<0.001)$, and interactions between duration and DCAD $(P=0.64)$, duration and day $(P=0.03)$, DCAD and day $(P=0.49)$, and duration and DCAD and day $(P=$ 0.84). Error bars represent the SEM; within a day, treatments with an asterisk differ $(P<0.05)$.

not differ with altering the level of DCAD. Once cows fed short were switched from a diet with +110 to either -70 or $-180 \mathrm{mEq} / \mathrm{kg}$ of DM, urinary $\mathrm{pH}$ declined within $24 \mathrm{~h}$ (data not shown) and $\mathrm{pH}$ remained stable according to treatment in the last $21 \mathrm{~d}$ of gestation, although an interaction $(P=0.03)$ between duration 
and day was observed because of the changes in the first days after diet switch (Figure 1D).

\section{Concentrations of Minerals and Metabolites in Blood Prepartum}

Duration of feeding acidogenic diets prepartum did not affect concentrations of minerals or metabolites in whole blood or plasma in the last $21 \mathrm{~d}$ of gestation (Supplemental Table S4; https://doi.org/10.3168/jds .2018-14580). Reducing the DCAD from -70 to -180 $\mathrm{mEq} / \mathrm{kg}$ of DM increased $(P=0.002)$ whole blood concentrations of $\mathrm{iCa}(1.233$ vs. $1.272 \pm 0.011 \mathrm{mM}$; Figure $2 \mathrm{~A})$. Nevertheless, DCAD did not affect concentrations of plasma tCa and tMg (Figure $2 \mathrm{~B}$ and $2 \mathrm{C}$ ) or whole blood concentrations of $\mathrm{Na}$ and $\mathrm{K}$. An interaction $(P=$ 0.008 ) between duration and DCAD was detected for plasma tP in part because, within cows receiving the $-70 \mathrm{mEq} / \mathrm{kg}$ of DM diets, those fed long had greater $(P<0.05)$ concentrations of plasma tP than cows fed short $\left(-70 \_\right.$short $=1.74$ vs. $-180 \_$short $=1.82$ vs. $-70 \_$long $=1.83$ vs. $-180 \_$long $=1.77 \pm 0.05 \mathrm{mM}$; Figure 2D). Treatment did not affect concentrations of glucose and BHB in plasma prepartum (Figures 3A and
$3 \mathrm{C})$; however, an interaction $(P=0.05)$ between duration and DCAD affected the concentrations of NEFA in plasma, and cows fed -180_short had greater $(P<$ 0.05) concentrations of plasma NEFA than cows fed $-180 \_$long $\left(-70 \_\right.$short $=0.260$ vs. $-180 \_$short $=0.314$ vs. $-70 \_$long $=0.275$ vs. $-180 \_$long $=0.239 \pm 0.027$ $\mathrm{m} M$; Figure 3B).

\section{Colostrum Yield and Composition}

Yield of first milking colostrum did not differ with duration of feeding, but it was greater $(P=0.04)$ for cows fed the -70 than the $-180 \mathrm{mEq} / \mathrm{kg}$ of DM diets (Table 3). Treatment did not affect concentrations of fat, lactose, TS, NE, Ca, Mg, IgG, and SCS. Tendencies $(P=0.09)$ for the effect of duration were observed for concentrations of true protein and SNF in first milking colostrum, although no statistical differences were observed among individual treatments after Tukey-protected pairwise comparisons. Duration of feeding did not affect yields of any of the components measured in colostrum; however, cows fed the $-70 \mathrm{mEq} / \mathrm{kg}$ of DM diet tended $(P \leq 0.09)$ to produce more true protein and SNF in colostrum, and produced more $(P=0.03)$

Table 2. Effects of duration (DUR) of prepartum feeding and level of DCAD on measures of blood acid-base balance, and urinary pH and excretion of minerals in Holstein cows prepartum ${ }^{1}$

\begin{tabular}{|c|c|c|c|c|c|c|c|c|}
\hline \multirow[b]{2}{*}{ Item } & \multicolumn{2}{|c|}{ Short } & \multicolumn{2}{|c|}{ Long } & \multirow[b]{2}{*}{ SEM } & \multicolumn{3}{|c|}{$P$-value ${ }^{2}$} \\
\hline & -70 & -180 & -70 & -180 & & DUR & DCAD & $\mathrm{DUR} \times \mathrm{DCAD}$ \\
\hline \multicolumn{9}{|l|}{ Blood $^{3}$} \\
\hline $\mathrm{pH}$ & 7.424 & 7.385 & 7.417 & 7.381 & 0.009 & 0.47 & $<0.001$ & 0.86 \\
\hline Total $\mathrm{CO}_{2}, \mathrm{~m} M$ & 27.2 & 24.0 & 26.6 & 25.0 & 0.7 & 0.72 & $<0.001$ & 0.14 \\
\hline Saturation of $\mathrm{O}_{2}, \%$ & 58.1 & 59.4 & 59.5 & 57.7 & 2.5 & 0.94 & 0.89 & 0.47 \\
\hline $\mathrm{pCO}_{2}, \mathrm{~mm} \mathrm{Hg}$ & 40.1 & 37.8 & 39.5 & 39.9 & 0.9 & 0.36 & 0.22 & 0.07 \\
\hline Base excess, ${ }^{4} \mathrm{~m} M$ & 1.75 & -2.26 & 1.07 & -1.43 & 0.78 & 0.91 & $<0.001$ & 0.23 \\
\hline \multicolumn{9}{|l|}{ Urine } \\
\hline $\mathrm{pH}^{5}$ & 6.46 & 5.62 & 6.48 & 5.56 & 0.14 & 0.81 & $<0.001$ & 0.64 \\
\hline Creatinine ${ }^{6} \mathrm{mg} / \mathrm{L}$ & 642 & 519 & 673 & 508 & 66 & 0.84 & $<0.001$ & 0.62 \\
\hline $\mathrm{L} / \mathrm{d}^{6}$ & 33.5 & 42.8 & 32.6 & 43.0 & 4.3 & 0.88 & $<0.001$ & 0.82 \\
\hline $\mathrm{Ca},{ }^{6} \mathrm{mg} / \mathrm{L}$ & 233 & 319 & 259 & 318 & 31 & 0.64 & 0.007 & 0.63 \\
\hline $\mathrm{Ca}^{6}{ }^{6} \mathrm{~g} / \mathrm{d}$ & 6.48 & 11.06 & 6.86 & 11.06 & 0.91 & 0.81 & $<0.001$ & 0.81 \\
\hline
\end{tabular}

${ }^{1}$ Cows were fed the following diets according to treatment: $-70 \_$short $=$diet containing $+110 \mathrm{mEq} / \mathrm{kg}$ of DM from 232 to $254 \mathrm{~d}$ of gestation, followed by a diet with $-70 \mathrm{mEq} / \mathrm{kg}$ of DM from $255 \mathrm{~d}$ of gestation to calving; -180 short = diet containing $+110 \mathrm{mEq} / \mathrm{kg}$ of DM from 232 to $254 \mathrm{~d}$ of gestation, followed by a diet with $-180 \mathrm{mEq} / \mathrm{kg}$ of DM from $255 \mathrm{~d}$ of gestation to calving; $-70 \_$long $=$diet containing $-70 \mathrm{mEq} / \mathrm{kg}$ of DM from $232 \mathrm{~d}$ of gestation to calving; -180_long = diet containing $-180 \mathrm{mEq} / \mathrm{kg}$ of DM from $232 \mathrm{~d}$ of gestation to calving.

${ }^{2}$ DUR $=$ effect of feeding duration $(42$ vs. $21 \mathrm{~d}) ; \mathrm{DCAD}=$ effect of level of DCAD $(-70$ vs. -180$)$; DUR $\times$ DCAD $=$ effect of interaction between DUR and DCAD (-70_short plus -180_long vs. -180_short plus -70_long).

${ }^{3}$ Jugular whole blood sampled and analyzed at 268 and $272 \mathrm{~d}$ of gestation, corresponding to -10 and $-6 \mathrm{~d}$ relative to calving. $\mathrm{pO}_{2}=$ partial pressure of $\mathrm{O}_{2} ; \mathrm{pCO}_{2}=$ partial pressure of $\mathrm{CO}_{2}$.

${ }^{4}$ Base excess calculated using the formula: Base excess $\mathrm{m} M=\left[\mathrm{HCO}_{3}{ }^{-}-24.8+16.2\right.$ (blood pH -7.4$\left.)\right]$ (CLSI, 2001).

${ }^{5}$ Urine sampled and analyzed from $256 \mathrm{~d}$ of gestation to calving.

${ }^{6}$ Urine sampled and analyzed in the last 2 wk of gestation. Urinary volume was estimated based on creatinine concentration (Valadares et al., 1999). 

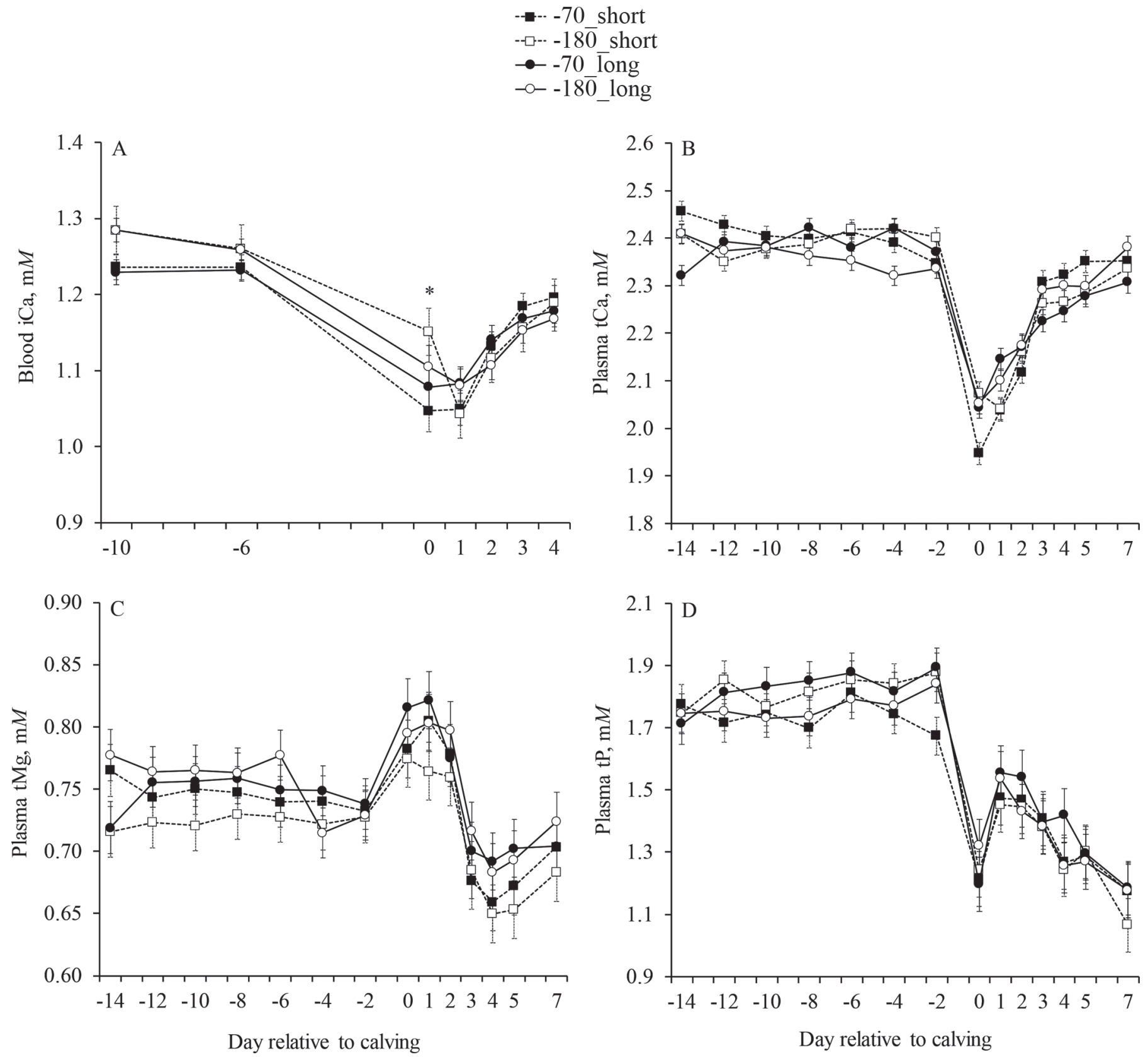

Figure 2. Concentrations of whole blood ionized $\mathrm{Ca}$ (iCa, A), plasma total $\mathrm{Ca}$ (tCa, B), plasma total $\mathrm{Mg}(\mathrm{tMg}, \mathrm{C})$, and plasma total $\mathrm{P}$ $(\mathrm{tP}, \mathrm{D})$ in dairy cows fed prepartum acidogenic diets of short $(21 \mathrm{~d})$ or long $(42 \mathrm{~d})$ durations of feeding and with $-70 \mathrm{or}-180 \mathrm{mEq} / \mathrm{kg}$ of $\mathrm{DM}$ (-70_short, -180_short, -70_long, and -180_long). (A) Prepartum interactions between duration and day $(P=0.95)$, DCAD and day $(P$ $=0.10)$, and duration and DCAD and day $(P=0.90)$; postpartum interactions between duration and day $(P=0.14)$, DCAD and day $(*, P$ $=0.04)$, and duration and DCAD and day $(P=0.46)$. (B) Prepartum interactions between duration and day $(P=0.38)$, DCAD and day $(P$ $=0.31)$, and duration and DCAD and day $(P=0.004)$; postpartum interactions between duration and day $(P=0.31)$, DCAD and day $(P=$ $0.22)$, and duration and DCAD and day $(P=0.24)$. (C) Prepartum interactions between duration and day $(P=0.10)$, DCAD and day $(P=$ $0.11)$, and duration and DCAD and day $(P=0.006)$; postpartum interactions between duration and day $(P=0.94), \mathrm{DCAD}$ and day $(P=0.30)$, and duration and DCAD and day $(P=0.67)$. (D) Prepartum interactions between duration and day $(P=0.61)$, DCAD and day $(P=0.58)$, and duration and DCAD and day $(P=0.22)$; postpartum interactions between duration and day $(P=0.72)$, DCAD and day $(P=0.53)$, and duration and DCAD and day $(P=0.76)$. Error bars represent SEM. 

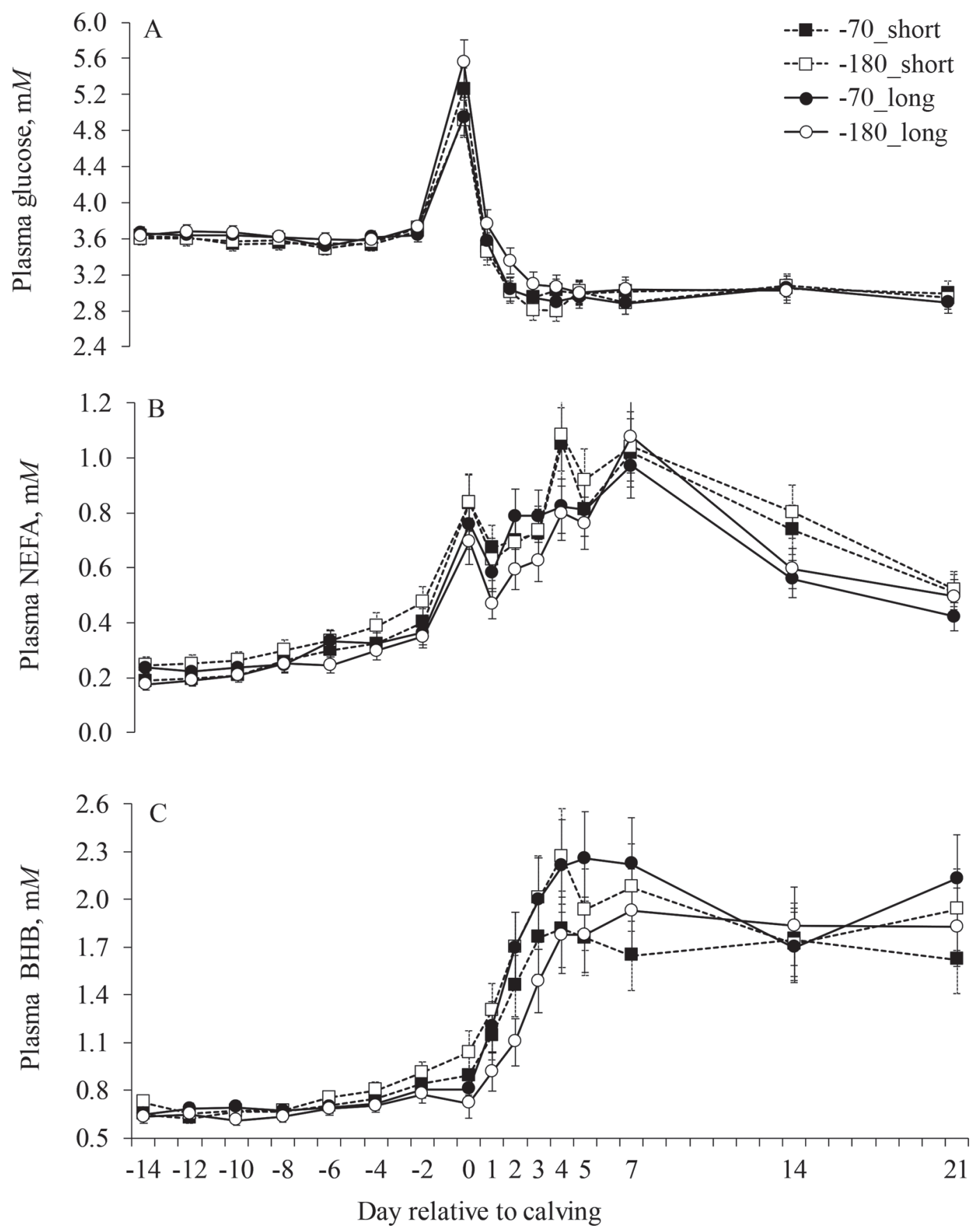

Figure 3. Concentrations of glucose (A), nonesterified fatty acids (NEFA) (B), and BHB (C) in plasma of dairy cows fed prepartum acidogenic diets of short $(21 \mathrm{~d})$ or long $(42 \mathrm{~d})$ durations of feeding and with -70 or $-180 \mathrm{mEq} / \mathrm{kg}$ of DM (-70_short, -180_short, -70_long, and -180_long). (A) Prepartum interactions between duration and day $(P=0.65)$, DCAD and day $(P=0.88)$, and duration and DCAD and day $(P=0.65)$; postpartum interactions between duration and day $(P=0.95)$, DCAD and day $(P=0.98)$, and duration and DCAD and day $(P=$ $0.42)$. (B) Prepartum interactions between duration and day $(P=0.88)$, DCAD and day $(P=0.56)$, and duration and DCAD and day $(P=$ $0.47)$; postpartum interactions between duration and day $(P=0.08)$, DCAD and day $(P=0.49)$, and duration and DCAD and day $(P=0.77)$.

(C) Prepartum interactions between duration and day $(P=0.21)$, DCAD and day $(P=0.59)$, and duration and DCAD and day $(P=0.98)$; postpartum interactions between duration and day $(P=0.43)$, DCAD and day $(P=0.93)$, and duration and DCAD and day $(P=0.45)$. Error bars represent the SEM. 
Table 3. Effects of duration (DUR) of prepartum feeding and level of DCAD on colostrum yield and composition in Holstein cows ${ }^{1}$

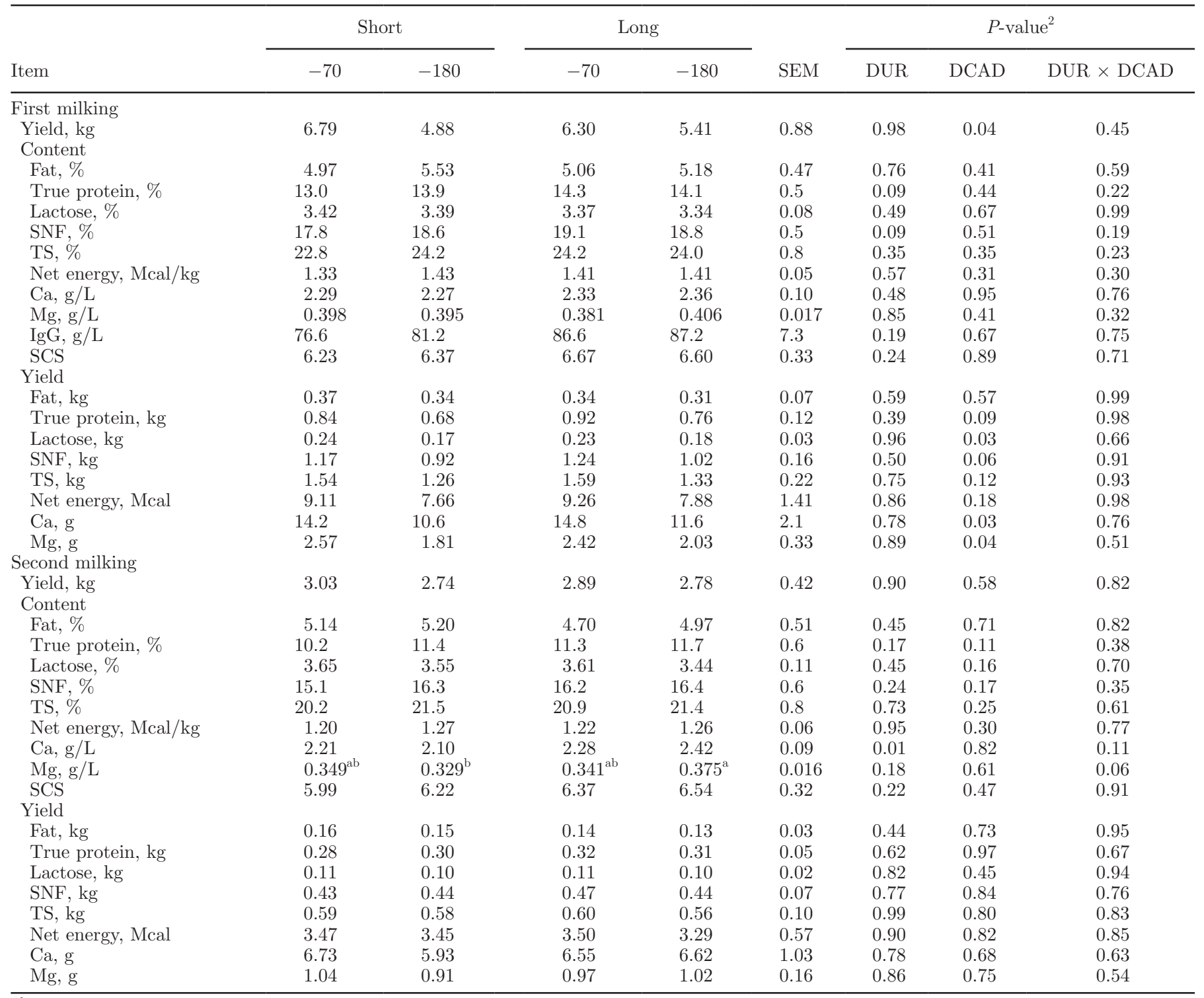

${ }^{\mathrm{a}, \mathrm{b}}$ Superscripts in the same row differ $(P<0.05)$ after adjustment by the method of Tukey.

${ }^{1}$ Cows were fed the following diets according to treatment: $-70 \_$short $=$diet containing $+110 \mathrm{mEq} / \mathrm{kg}$ of DM from 232 to $254 \mathrm{~d}$ of gestation, followed by a diet with $-70 \mathrm{mEq} / \mathrm{kg}$ of DM from $255 \mathrm{~d}$ of gestation to calving; -180_short = diet containing $+110 \mathrm{mEq} / \mathrm{kg}$ of DM from 232 to $254 \mathrm{~d}$ of gestation, followed by a diet with $-180 \mathrm{mEq} / \mathrm{kg}$ of DM from $255 \mathrm{~d}$ of gestation to calving; $-70 \_$long $=$diet containing $-70 \mathrm{mEq} / \mathrm{kg}$ of DM from $232 \mathrm{~d}$ of gestation to calving; -180_long = diet containing $-180 \mathrm{mEq} / \mathrm{kg}$ of DM from $232 \mathrm{~d}$ of gestation to calving.

${ }^{2}$ DUR $=$ effect of feeding duration $(42$ vs. $21 \mathrm{~d}) ;$ DCAD $=$ effect of level of DCAD ( -70 vs. -180$)$; DUR $\times$ DCAD $=$ effect of interaction between DUR and DCAD (-70_short plus -180_long vs. -180_short plus -70_long).

lactose and secreted more $(P<0.05) \mathrm{Ca}$ and $\mathrm{Mg}$ than cows fed the $-180 \mathrm{mEq} / \mathrm{kg}$ of $\mathrm{DM}$ diet.

Dietary treatments had minor effects on second milking colostrum yield and composition (Table 3). Neither duration of feeding nor level of DCAD affected concentrations of fat, true protein, lactose, SNF, TS, and $\mathrm{NE}_{\mathrm{L}}$ in second milking colostrum. The concentration of $\mathrm{Ca}$ in second milking colostrum was greater $(P=$ 0.01) in cows fed long than short, whereas that of $\mathrm{Mg}$ was greater $(P=0.05)$ only in cows fed $-180 \_$long compared with -180_short. Yields of second milking colostrum and components in second milking colostrum did not differ with treatment.

\section{Lactation Performance}

Increasing the duration of feeding acidogenic diets prepartum from 21 to $42 \mathrm{~d}$ reduced $(P=0.03)$ milk 
Table 4. Effects of duration (DUR) of prepartum feeding and level of DCAD on productive performance in the first $42 \mathrm{~d}$ postpartum in Holstein cows $^{1}$

\begin{tabular}{|c|c|c|c|c|c|c|c|c|}
\hline Item & \multicolumn{2}{|c|}{ Short } & \multicolumn{2}{|c|}{ Long } & SEM & \multicolumn{3}{|c|}{$P$-value ${ }^{2}$} \\
\hline Milk, kg/d & 41.1 & 39.6 & 37.5 & 38.6 & 1.3 & 0.03 & 0.93 & 0.25 \\
\hline $\mathrm{ECM}, \mathrm{kg} / \mathrm{d}$ & 42.8 & 42.2 & 40.4 & 41.2 & 1.4 & 0.14 & 0.91 & 0.56 \\
\hline \multicolumn{9}{|l|}{ Fat } \\
\hline$\%$ & 4.11 & 4.27 & 4.33 & 4.26 & 0.11 & 0.24 & 0.60 & 0.22 \\
\hline$\%$ & 2.97 & 3.01 & 3.05 & 3.05 & 0.05 & 0.17 & 0.56 & 0.70 \\
\hline Yield, kg & 1.20 & 1.18 & 1.12 & 1.15 & 0.04 & 0.14 & 0.92 & 0.48 \\
\hline \multicolumn{9}{|l|}{ Lactose } \\
\hline$\%$ & 4.58 & 4.60 & 4.60 & 4.59 & 0.03 & 0.91 & 0.93 & 0.73 \\
\hline Yield, kg & 1.90 & 1.84 & 1.74 & 1.79 & 0.06 & 0.04 & 0.94 & 0.32 \\
\hline \multicolumn{9}{|l|}{$\mathrm{SNF}$} \\
\hline$\%$ & 8.41 & 8.47 & 8.51 & 8.51 & 0.06 & 0.23 & 0.65 & 0.66 \\
\hline \multicolumn{9}{|l|}{ BW } \\
\hline \multicolumn{9}{|l|}{ Body condition } \\
\hline Score, 1 to 5 & 3.27 & 3.36 & 3.35 & 3.26 & 0.06 & 0.84 & 0.99 & 0.14 \\
\hline Change, wk 1 to 6 & -0.248 & -0.228 & -0.257 & -0.291 & 0.075 & 0.78 & 0.87 & 0.49 \\
\hline
\end{tabular}

${ }^{1}$ Cows were fed the following diets according to treatment: $-70 \_$short $=$diet containing $+110 \mathrm{mEq} / \mathrm{kg}$ of DM from 232 to $254 \mathrm{~d}$ of gestation, followed by a diet with $-70 \mathrm{mEq} / \mathrm{kg}$ of DM from $255 \mathrm{~d}$ of gestation to calving; $-180 \_$short = diet containing $+110 \mathrm{mEq} / \mathrm{kg}$ of DM from 232 to $254 \mathrm{~d}$ of gestation, followed by a diet with $-180 \mathrm{mEq} / \mathrm{kg}$ of DM from $255 \mathrm{~d}$ of gestation to calving; $-70 \_$long $=$diet containing $-70 \mathrm{mEq} / \mathrm{kg}$ of DM from $232 \mathrm{~d}$ of gestation to calving; -180_long = diet containing $-180 \mathrm{mEq} / \mathrm{kg}$ of DM from $232 \mathrm{~d}$ of gestation to calving.

${ }^{2} \mathrm{DUR}=$ effect of feeding duration $(42 \mathrm{vs} .21 \mathrm{~d}) ; \mathrm{DCAD}=$ effect of level of DCAD $(-70 \mathrm{vs} .-180)$; DUR $\times$ DCAD $=$ effect of interaction between DUR and DCAD (-70_short plus -180_long vs. -180_short plus -70_long).

yield by $2.5 \mathrm{~kg} / \mathrm{d}$ (short $=40.4$ vs. long $=37.9 \pm 1.0$ $\mathrm{kg} / \mathrm{d}$; Table 4; Figure 4A). Nevertheless, yields of $3.5 \%$ FCM and ECM did not differ with treatment (Table 4; Figure 4B). Altering the level of DCAD did not affect yields of milk, 3.5\% FCM, or ECM. Treatment did not influence concentrations and yields of fat and true protein in milk; however, the reduced milk yield in cows receiving the long compared with the short treatments resulted in less $(P=0.04)$ yield of lactose and a tendency $(P=0.06)$ for less yield of SNF for those cows. The SCS did not differ with treatment. As expected, cows lost BW (Figure 4C) and body condition (Figure $4 \mathrm{D})$, but the mean BW and BCS and the losses in the first $42 \mathrm{~d}$ postpartum did not differ among treatments (Table 4).

\section{Acid-Base Balance Postpartum}

Duration of prepartum feeding of acidogenic diets did not influence any of the measures of acid-base status in blood postpartum (Supplemental Table S5; https://doi .org/10.3168/jds.2018-14580). Blood $\mathrm{pH}$ postpartum tended $(P=0.09)$ to be less for cows fed the -70 than those fed the $-180 \mathrm{mEq} / \mathrm{kg}$ of $\mathrm{DM}$ diets prepartum (7.449 vs. $7.455 \pm 0.003$ ). Feeding $-70 \mathrm{mEq} / \mathrm{kg}$ of $\mathrm{DM}$ of DCAD prepartum caused a slight reduction $(P<$
$0.05)$ in $\mathrm{tCO}_{2}(30.10$ vs. $30.88 \pm 0.31 \mathrm{mM})$, bicarbonate ( 28.9 vs. $29.7 \pm 0.3 \mathrm{mM}$ ), and base excess ( 4.87 vs. 5.77 $\pm 0.32 \mathrm{mM}$ ), although the reduction in bicarbonate was only evident in $-70 \_$long cows $\left(-70 \_\right.$short $=29.2$ vs. $-180 \_$short $=29.3$ vs. $-70 \_$long $=28.6$ vs. $-180 \_$long $=30.0 \pm 0.4 \mathrm{mM}$; Supplemental Table S5).

\section{Blood Concentrations of Minerals and Metabolites Postpartum}

Concentrations of $\mathrm{iCa}$, tCa, and tP sharply declined $(P<0.001)$ on the day of calving, whereas those of $\mathrm{tMg}$ increased with the onset of lactation (Figure 2A-D). Treatments did not influence concentrations of iCa, tCa, tP, and $\mathrm{Na}$ in the first days postpartum (Table $5)$, although an interaction $(P=0.04)$ between DCAD and day postpartum was observed for iCa because cows fed $-180 \mathrm{mEq} / \mathrm{kg}$ of $\mathrm{DM}$ of DCAD had greater iCa concentrations on the day of calving than those fed $-70 \mathrm{mEq} / \mathrm{kg}$ of DM of DCAD prepartum (Figure $2 \mathrm{~A}$ ). Cows fed -70_long and -180 long had greater $(P=$ 0.05) concentrations of $\mathrm{tMg}$ than those fed -70_short and -180 short. An interaction $(P=0.008)$ between duration and DCAD affected blood $\mathrm{K}$ in the first 4 DIM because cows fed $-180 \_$short had a smaller $(P<$ 


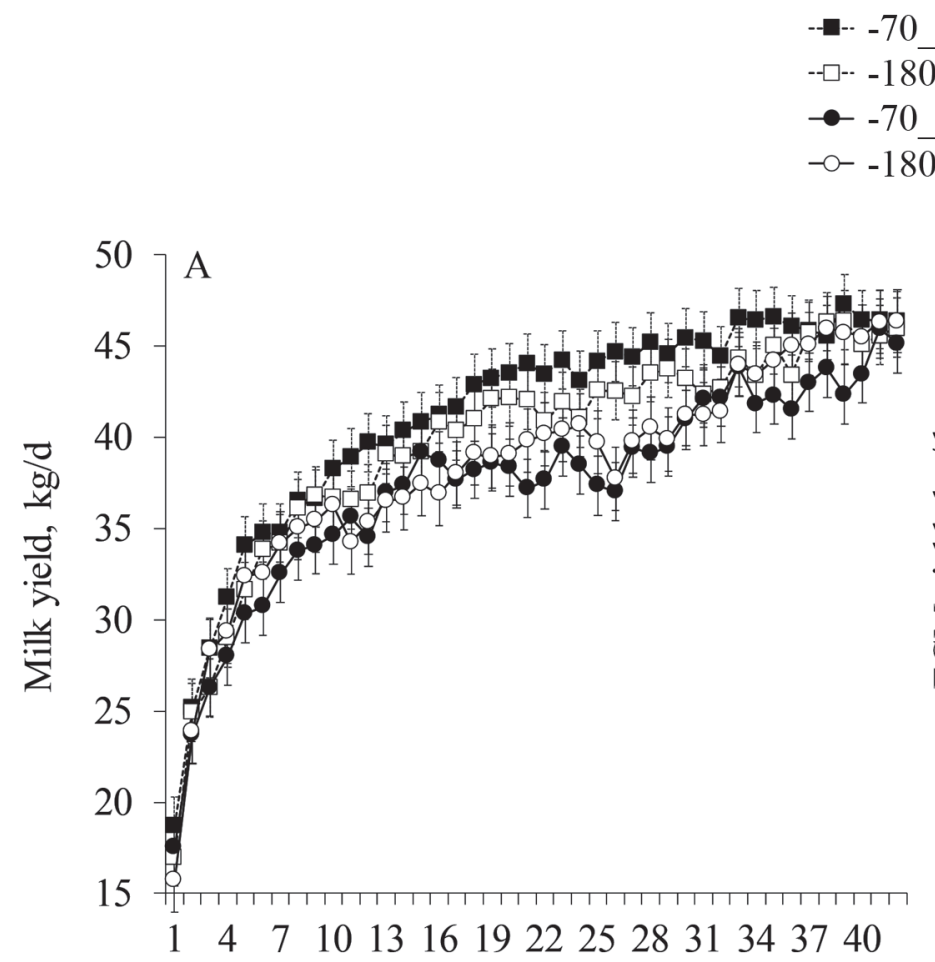

Day postpartum
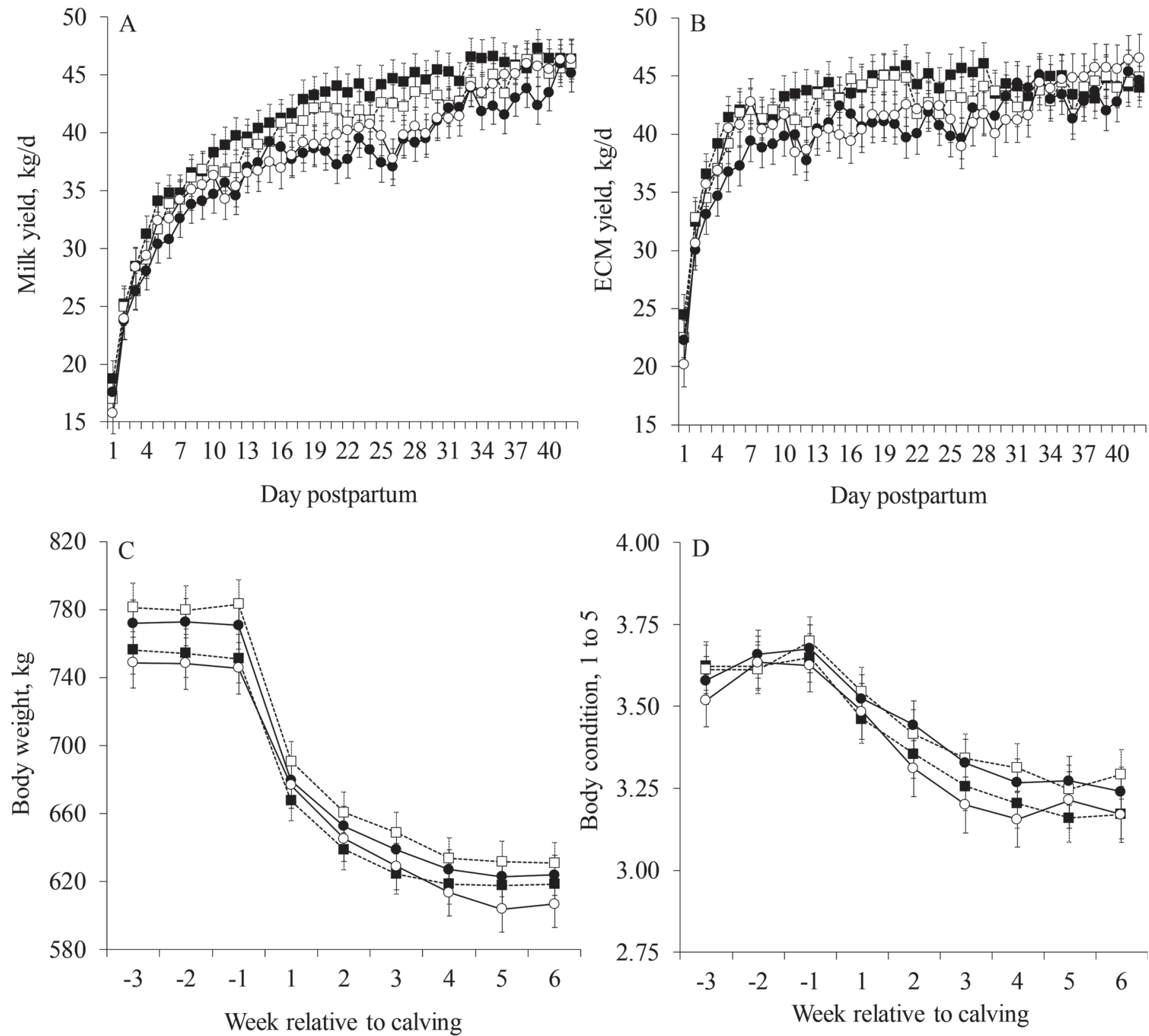

Day postpartum

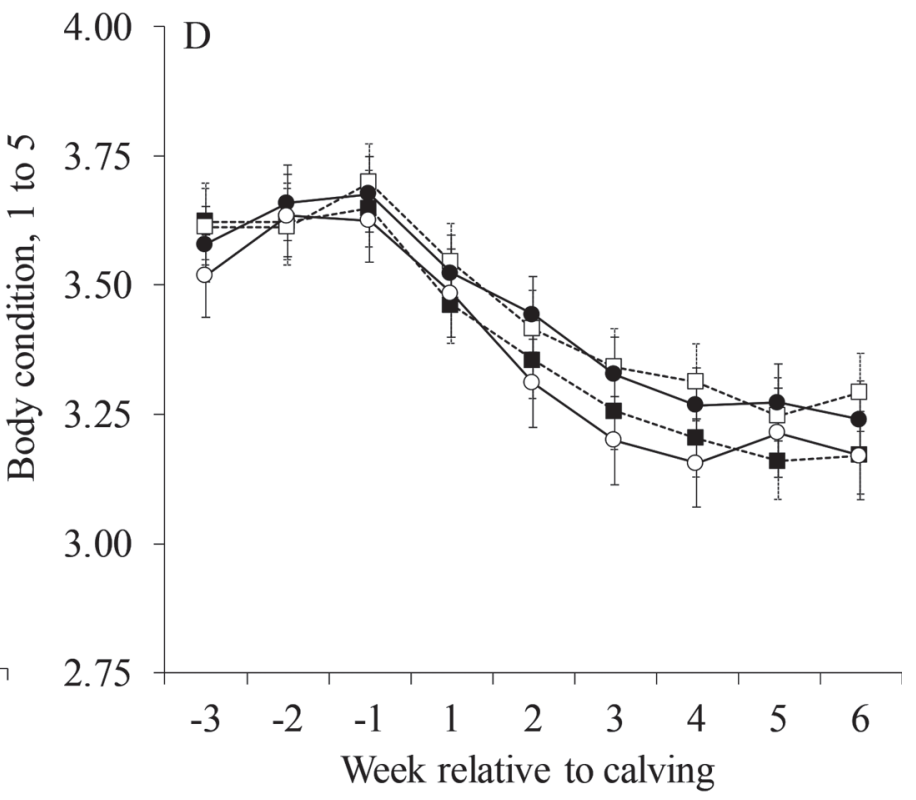

Figure 4. Yields of milk (A) and ECM (B), BW (C), and BCS (D) of dairy cows fed prepartum acidogenic diets of short (21 d) or long (42 d) durations and with -70 or $-180 \mathrm{mEq} / \mathrm{kg}$ of DM (-70_short, -180_short, -70_long, and -180_long). (A) Interactions between duration and day $(P=0.001)$, DCAD and day $(P=0.96)$, and duration and DCAD and day $(P=0.96)$. (B) Interactions between duration and day $(P$ $<0.001)$, DCAD and day $(P=0.55)$, and duration and DCAD and day $(P=0.71)$. (C) Prepartum interactions between duration and week $(P$ $=0.66)$, DCAD and week $(P=0.65)$, and duration and DCAD and week $(P=0.42)$; postpartum interactions between duration and week $(P=$ $0.35)$, DCAD and week $(P=0.19)$, and duration and DCAD and week $(P=0.72)$. (D) Prepartum interactions between duration and day $(P=$ $0.08)$, DCAD and week $(P=0.61)$, and duration and DCAD and week $(P=0.61)$; postpartum interactions between duration and week $(P=$ $0.10)$, DCAD and week $(P=0.66)$, and duration and DCAD and week $(P=0.78)$. Error bars represent SEM. 
0.05) concentration of $\mathrm{K}$ than those fed -70_short or -180_long.

Concentrations of glucose in plasma sharply increased $(P<0.001)$ on the day of calving to $5.18 \pm 0.22 \mathrm{mM}$, and then declined to approximately $2.95 \pm 0.13 \mathrm{~m} M$ by $3 \mathrm{~d}$ postpartum (Figure 3A). Increases in plasma NEFA and BHB concentrations with the onset of lactation were also observed, but they were not as acute, and their concentrations remained elevated until $21 \mathrm{~d}$ postpartum (Figure 3B and 3C). An interaction $(P=0.05)$ between duration of feeding and DCAD affected mean plasma glucose postpartum because concentrations were greater for cows fed -70_short and -180_long than -180_short and -70_long, although pairwise comparisons did not detect differences among individual treatments (Table 5$)$. An interaction $(P=0.04)$ between duration and DCAD also affected plasma BHB concentrations, and cows fed -70_short and -180_long had less BHB than cows fed -180_short and -70_long. Similar to plasma glucose, pairwise comparisons did not detect differences among individual treatments for plasma BHB concentrations. Cows fed short tended $(P$ $=0.09)$ to have greater NEFA concentrations in plasma than those fed long.

\section{Health and Survival}

Two cows had milk fever, 1 fed -70_short and 1 fed -180_short. One cow fed -70_short developed milk fever approximately $12 \mathrm{~h}$ before calving, and the blood
iCa concentration immediately before treatment with i.v. Ca solution was $0.58 \mathrm{~m} M$. Twenty-four hours later, whole blood iCa was $1.16 \mathrm{mM}$. The second cow, fed -180_short, was diagnosed with milk fever hours after milking colostrum and blood iCa was $0.61 \mathrm{mM}$; she also recovered after i.v. Ca solution.

Treatment did not affect the incidence of retained placenta, metritis, puerperal metritis, mastitis, or displaced abomasum (Table 6). Morbidity affected $32.7 \%$ of the experimental cows and $15.1 \%$ of them were diagnosed with more than 1 clinical disease in the first 42 DIM.

The incidence of subclinical hypocalcemia changed according to threshold selected. It was lowest when based on whole blood iCa $\leq 1.0 \mathrm{~m} M$, intermediate when based on $\mathrm{tCa} \leq 2.0 \mathrm{mM}$, and highest when based on $\mathrm{tCa}$ $<2.15 \mathrm{~m} M$ (Table 6). Nevertheless, despite the threshold used, treatments did not influence the incidence of subclinical hypocalcemia postpartum. Similarly, the daily prevalence of subclinical hypocalcemia changed with threshold selected and followed the same pattern as that of incidence of subclinical hypocalcemia (Figure $5)$. The daily prevalence of subclinical hypocalcemia declined $(P<0.001)$ with day postpartum regardless of threshold used, but neither treatment nor interaction between treatment and day affected the daily prevalence of subclinical hypocalcemia.

By 42 DIM, $7.1 \%$ of the cows enrolled in the experiment had been sold or died, and this number increased to $21.2 \%$ by 305 d postpartum (Table 6 ). Duration of

Table 5. Effects of duration (DUR) of prepartum feeding and level of DCAD on blood concentrations of minerals and metabolites in Holstein cows postpartum

\begin{tabular}{|c|c|c|c|c|c|c|c|c|}
\hline \multirow[b]{2}{*}{ Item } & \multicolumn{2}{|c|}{ Short } & \multicolumn{2}{|c|}{ Long } & \multirow[b]{2}{*}{ SEM } & \multicolumn{3}{|c|}{$P$-value ${ }^{2}$} \\
\hline & -70 & -180 & -70 & -180 & & DUR & DCAD & $\mathrm{DUR} \times \mathrm{DCAD}$ \\
\hline Plasma tMg, ${ }^{4} \mathrm{~m} M$ & 0.725 & 0.710 & 0.744 & 0.745 & 0.019 & 0.05 & 0.57 & 0.55 \\
\hline Plasma $\mathrm{tP}_{3}^{4} \mathrm{~m} M$ & 1.33 & 1.30 & 1.37 & 1.34 & 0.06 & 0.44 & 0.59 & 0.94 \\
\hline Blood $\mathrm{Na}^{3} \mathrm{mM}$ & 143.0 & 143.0 & 143.2 & 143.1 & 0.4 & 0.62 & 0.89 & 0.90 \\
\hline Plasma NEFA, ${ }^{5} \mathrm{~m} M$ & 0.769 & 0.788 & 0.704 & 0.659 & 0.067 & 0.09 & 0.79 & 0.56 \\
\hline Plasma BHB, ${ }^{5} \mathrm{~m} M$ & 1.50 & 1.73 & 1.72 & 1.41 & 0.15 & 0.67 & 0.72 & 0.04 \\
\hline
\end{tabular}

\footnotetext{
${ }^{\mathrm{a}, \mathrm{b}}$ Superscripts in the same row differ $(P<0.05)$ after adjustment by the method of Tukey.

${ }^{1}$ Cows were fed the following diets according to treatment: $-70 \_$short $=$diet containing $+110 \mathrm{mEq} / \mathrm{kg}$ of DM from 232 to $254 \mathrm{~d}$ of gestation, followed by a diet with $-70 \mathrm{mEq} / \mathrm{kg}$ of DM from $255 \mathrm{~d}$ of gestation to calving; -180 short = diet containing $+110 \mathrm{mEq} / \mathrm{kg}$ of DM from 232 to $254 \mathrm{~d}$ of gestation, followed by a diet with $-180 \mathrm{mEq} / \mathrm{kg}$ of DM from $255 \mathrm{~d}$ of gestation to calving; $-70 \_l o n g=$ diet containing $-70 \mathrm{mEq} / \mathrm{kg}$ of DM from $232 \mathrm{~d}$ of gestation to calving; -180_long = diet containing $-180 \mathrm{mEq} / \mathrm{kg}$ of DM from $232 \mathrm{~d}$ of gestation to calving.

${ }^{2}$ DUR $=$ effect of feeding duration $(42 \mathrm{vs} .21 \mathrm{~d}) ;$ DCAD $=$ effect of level of DCAD $(-70$ vs. -180$)$; DUR $\times$ DCAD $=$ effect of interaction between DUR and DCAD (-70_short plus -180_long vs. -180_short plus -70_long).

${ }^{3}$ Jugular blood sampled on d 0, 1, 2, 3, and 4 postpartum and whole blood analyzed for concentrations of ionized Ca (iCa), Na, and K.

${ }^{4}$ Blood sampled by puncture of coccygeal vessels on $\mathrm{d} 0,1,2,3,4,5$, and 7 postpartum and plasma analyzed for concentrations of total (t) Ca, $\mathrm{tMg}$, and $\mathrm{tP}$.

${ }^{5}$ Blood sampled by puncture of coccygeal vessels on d $0,1,2,3,4,5,7,14$, and 21 and plasma analyzed for concentrations of glucose, nonesterified fatty acids (NEFA), and BHB.
} 
feeding or level of prepartum DCAD did not affect the risk of cows leaving the herd.

\section{Reproduction}

Of the 113 cows considered for analyses of data for reproductive responses, $101(89.3 \%)$ received at least 1 AI postpartum. Treatment did not influence the proportion of cows receiving AI (Table 7). Because of timed AI, days to first insemination did not differ among treatments. Pregnancy at first AI did not differ with treatment, but cows fed short had greater $(P$ $=0.03) \mathrm{P} / \mathrm{AI}$ after all $\mathrm{AI}$ than cows fed long (short $=35.0$ vs. long $=22.6 \%)$, which tended $(P=0.08)$ to increase the proportion of cows pregnant by $305 \mathrm{~d}$ postpartum ( short $=76.0$ vs. long $=60.0 \%$ ). In fact, the rate of pregnancy was $55 \%$ greater $(P=0.06)$ in cows fed short than those fed long (Figure 6A), which reduced the mean and median days to pregnancy. Level of DCAD did not influence reproduction in dairy cows (Figure 6B).

\section{DISCUSSION}

According to the USDA (2008, 2016), at least 30\% of the dairy farms in the United States use acidogenic diets to prevent hypocalcemia, and $60 \%$ separate prepartum cows into far-off and close-up groups during the dry period. The recommended range of DCAD in diets for prepartum cows has been suggested as -50 to $-150 \mathrm{mEq} / \mathrm{kg}$ of DM (NRC, 2001), although the ideal DCAD has not been established to optimize health and performance. Furthermore, some producers might opt to group prepartum cows together during the entire dry period, and some experiments suggested that feeding acidogenic diets longer than $21 \mathrm{~d}$ was not detrimental to early postpartum performance (Weich et al., 2013; Wu et al., 2014).

Increasing the duration of feeding acidogenic diets prepartum from 21 to 42 d reduced gestation length and milk yield and tended to compromise reproduction regardless of the level of DCAD fed. Concurrently, reducing the level of DCAD from -70 to $-180 \mathrm{mEq} / \mathrm{kg}$ of DM decreased prepartum DMI and produced a more pronounced metabolic acidosis. The more acidogenic diet attenuated the decrease of blood iCa concentration at calving and reduced colostrum yield at the first milking, but had no subsequent effect on production, health, or reproduction in dairy cows.

Acidogenic diets are well known to minimize the risk of hypocalcemia in dairy cows (Ender et al., 1971; Block, 1984), but they can affect intake prepartum. Charbonneau et al. (2006) demonstrated a linear decrease in DMI with a reduction in DCAD, which corroborates the findings from the present experiment. A potential palatability issue with acidogenic salts has been sug-

Table 6. Effects of duration (DUR) of prepartum feeding and level of DCAD on health in Holstein cows ${ }^{1}$

\begin{tabular}{|c|c|c|c|c|c|c|c|c|}
\hline \multirow[b]{2}{*}{ Item $^{3}$} & \multirow{2}{*}{$\begin{array}{l}\text { Incidence } \\
\text { (no./no.) }\end{array}$} & \multicolumn{2}{|c|}{ Short } & \multicolumn{2}{|c|}{ Long } & \multicolumn{3}{|c|}{$P$-value ${ }^{2}$} \\
\hline & & -70 & -180 & -70 & -180 & DUR & DCAD & $\mathrm{DUR} \times \mathrm{DCAD}$ \\
\hline Milk fever, $\%$ & $1.8(2 / 114)$ & 3.5 & 3.5 & 0 & 0 & - & - & - \\
\hline Retained placenta, \% & $14.0(16 / 114)$ & 13.8 & 13.8 & 17.9 & 10.7 & 0.92 & 0.87 & 0.80 \\
\hline Metritis, \% & $15.9(18 / 113)$ & 20.7 & 10.3 & 14.3 & 18.5 & 0.75 & 0.92 & 0.14 \\
\hline Puerperal metritis, $\%$ & $8.0(9 / 113)$ & 6.9 & 6.9 & 7.1 & 11.1 & 0.73 & 0.66 & 0.66 \\
\hline Mastitis, $\%$ & $12.4(14 / 113)$ & 13.8 & 10.3 & 14.3 & 11.1 & 0.94 & 0.73 & 0.95 \\
\hline Displaced abomasum, \% & $6.2(7 / 113)$ & 3.5 & 6.9 & 3.6 & 11.1 & 0.64 & 0.15 & 0.40 \\
\hline Morbidity, \% & $32.7(37 / 113)$ & 34.5 & 34.5 & 25.0 & 37.0 & 0.54 & 0.23 & 0.35 \\
\hline Multiple diseases, $\%$ & $15.1(14 / 113)$ & 17.2 & 10.3 & 21.4 & 11.1 & 0.66 & 0.35 & 0.89 \\
\hline \multicolumn{9}{|l|}{ Subclinical hypocalcemia ${ }^{4}$} \\
\hline Blood $\mathrm{iCa} \leq 1.0 \mathrm{~m} M, \%$ & $36.3(29 / 80)$ & 52.4 & 30.0 & 26.3 & 35.0 & 0.37 & 0.59 & 0.17 \\
\hline Plasma tCa $\leq 2.0 \mathrm{~m} M, \%$ & $57.9(66 / 114)$ & 62.1 & 58.6 & 64.3 & 46.4 & 0.61 & 0.27 & 0.45 \\
\hline Plasma tCa $<2.15 \mathrm{~m} M, \%$ & $85.1(97 / 114)$ & 86.2 & 79.3 & 92.9 & 82.1 & 0.43 & 0.19 & 0.63 \\
\hline \multicolumn{9}{|l|}{ Sold and dead, \% } \\
\hline 42 d postpartum & $7.1(8 / 113)$ & 2.7 & 5.5 & 8.4 & 6.1 & 0.45 & 0.82 & 0.54 \\
\hline 305 d postpartum & $21.2(24 / 113)$ & 24.1 & 13.8 & 25.0 & 22.2 & 0.51 & 0.37 & 0.57 \\
\hline
\end{tabular}

${ }^{1}$ Cows were fed the following diets according to treatment: $-70 \_$short $=$diet containing $+110 \mathrm{mEq} / \mathrm{kg}$ of DM from 232 to $254 \mathrm{~d}$ of gestation, followed by a diet with $-70 \mathrm{mEq} / \mathrm{kg}$ of DM from $255 \mathrm{~d}$ of gestation to calving; - 180_short = diet containing $+110 \mathrm{mEq} / \mathrm{kg}$ of DM from 232 to $254 \mathrm{~d}$ of gestation, followed by a diet with $-180 \mathrm{mEq} / \mathrm{kg}$ of DM from $255 \mathrm{~d}$ of gestation to calving; $-70 \_$long $=$diet containing $-70 \mathrm{mEq} / \mathrm{kg}$ of DM from $232 \mathrm{~d}$ of gestation to calving; -180_long = diet containing $-180 \mathrm{mEq} / \mathrm{kg}$ of DM from $232 \mathrm{~d}$ of gestation to calving.

${ }^{2}$ DUR $=$ effect of feeding duration $(42$ vs. $21 \mathrm{~d}) ; \mathrm{DCAD}=$ effect of level of DCAD $(-70 \mathrm{vs} .-180) ; \mathrm{DUR} \times \mathrm{DCAD}=$ effect of interaction between DUR and DCAD (-70_short plus -180_long vs. -180_short plus -70_long).

${ }^{3}$ Data collected until 42 d postpartum.

${ }^{4}$ Based on at least 1 blood sample with value below the indicated threshold with samples collected on $\mathrm{d} 0,1,2,3$, and 4 postpartum. $\mathrm{i}=$ ionized; $\mathrm{t}=$ total. 

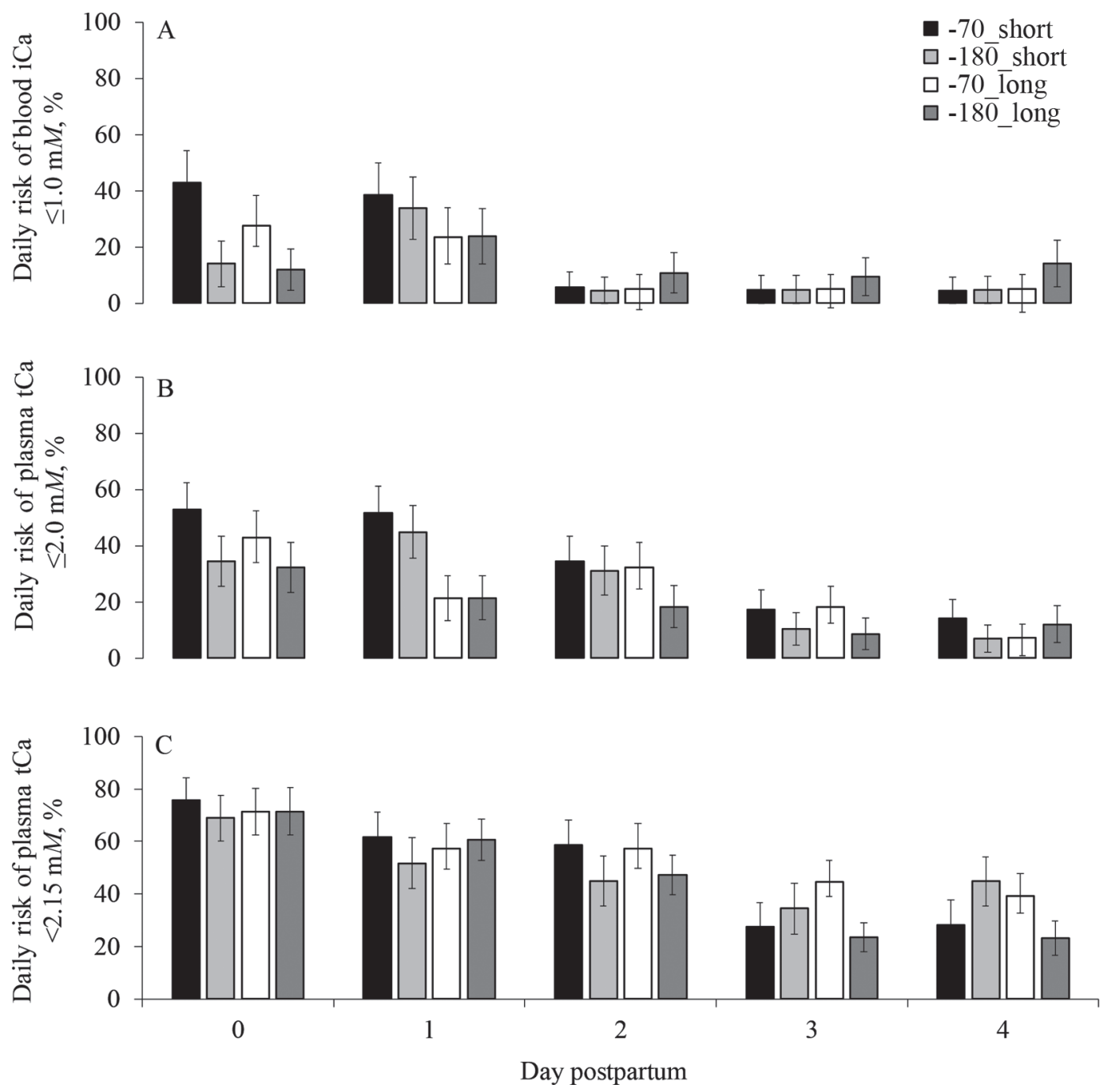

Figure 5. Daily risk of subclinical hypocalcemia based on concentration of ionized Ca (iCa) $\leq 1.0 \mathrm{~m} M$ in whole blood (A), plasma total Ca $(\mathrm{tCa}) \leq 2.0 \mathrm{~m} M$ in plasma (B), or tCa $<2.15 \mathrm{~m} M$ in plasma (C) in cows fed prepartum acidogenic diets of short (21 d) or long (42 d) durations and with -70 or $-180 \mathrm{mEq} / \mathrm{kg}$ of DM. (A) Mean daily risks averaged 12.8, 9.1, 10.0, and $13.3 \pm 6.4 \%$ for $-70 \_$short, $-180 \_$short, $-70 \_$long, and -180_long; effects of duration $(P=0.91)$, DCAD $(P=0.96)$, day $(P<0.001)$, and interactions between duration and DCAD $(P=0.59)$, duration and day $(P=0.61)$. DCAD and day $(P=0.11)$, and duration and DCAD and day $(P=0.97)$. (B) Mean daily risks averaged 31.6, 21.7, 21.7, and $17.1 \pm 5.5 \%$ for $-70 \_$short, $-180 \_$short, $-70 \_$long, and $-180 \_$long; effects of duration $(P=0.21)$, DCAD $(P=0.21)$, day $(P<0.001)$, and interactions between duration and $\operatorname{DCAD}(P=0.73)$, duration and day $(P=0.15)$, DCAD and day $(P=0.71)$, and duration and DCAD and day $(P=0.66)$. $(\mathrm{C})$ Mean daily risks averaged 50.2, 49.1, 54.2, and $44.3 \pm 6.3 \%$ for $-70 \_$short, $-180 \_$short, $-70 \_l o n g$, and $-180 \_l o n g ;$ effects of duration $(P=0.95)$, DCAD $(P=0.39)$, day $(P<0.001)$, and interactions between duration and DCAD $(P=0.50)$, duration and day $(P=0.95), \mathrm{DCAD}$ and day $(P=0.88)$, and duration and DCAD and day $(P=0.32)$. Error bars represent SEM.

gested to be the cause of less appetite, although in some cases experiments used high-Cl and -S products and not necessarily a particular salt (Vagnoni and Oetzel, 1998; Martinez et al., 2018). Vagnoni and Oetzel (1998) supplemented cows with different acidogenic products to reduce the DCAD of diets fed to dry cows. Those authors showed that acidogenic diets reduced DMI regardless of the source of strong anions fed; they suggested that the decrease in DMI may be explained by discomfort generated by the metabolic acidosis rather than the palatability of the acidogenic products (Vagnoni and Oetzel, 1998). We recently showed that the reduction in appetite and changes in feeding behavior are induced by the changes in acid-base status and not by feeding acidogenic product per se (Zimpel et al., 2018). Cows fed an acidogenic product to reduce the DCAD had depressed DMI, but supplementing alkalogenic salts to avoid the decrease in DCAD induced by the acidogenic diet prevented the decline in DMI (Zimpel et al., 2018). In consequence to the decrease 
in DMI, cows fed the $-180 \mathrm{mEq} / \mathrm{kg}$ of DM DCAD had less caloric intake and, consequently, a smaller NE balance that led to a greater BCS loss prepartum.

Reducing the DCAD of prepartum diets from 183 to $-74 \mathrm{mEq} / \mathrm{kg}$ of DM improved yields of milk and ECM in the first 3 wk of lactation in dairy cows (Leno et al., 2017). Nevertheless, increasing the duration of feeding acidogenic diets prepartum in the present experiment from 21 to $42 \mathrm{~d}$ reduced milk yield in the first $42 \mathrm{~d}$ postpartum by $2.5 \mathrm{~kg} / \mathrm{d}$. Although yields of $3.5 \% \mathrm{FCM}$ and ECM did not differ with treatments. In observational studies, production of fat and protein-corrected milk was optimized when cows were fed transition diets for approximately $25 \mathrm{~d}$ (Degaris et al., 2008). In controlled experiments, feeding acidogenic diets up to $42 \mathrm{~d}$ prepartum did not influence early lactation milk yield compared with feeding for $21 \mathrm{~d}$ (Weich et al., 2013; Wu et al., 2014). Although cows in Weich et al. (2013) and Wu et al. (2014) received diets with DCAD of -150 and $-200 \mathrm{mEq} / \mathrm{kg}$ of $\mathrm{DM}$, respectively, the responses in acid-base balance were more moderate than those observed in the current experiment in cows fed the -180 $\mathrm{mEq} / \mathrm{kg}$ of DM diet. Also, cows fed long had gestation length decreased by $2 \mathrm{~d}$ compared with those fed short, and it is possible that a reduction in gestation length might have affected mammogenesis and subsequent milk yield (Capuco et al., 1997; Vieira-Neto et al., 2017a). The last weeks of gestation determine most mammary development, and number of milk secreting cells depends on length of dry period. Capuco et al.
(1997) characterized the cytological changes of bovine mammary gland during the weeks after milk cessation and documented that nearly all alveolar cells display characteristics of cells competent for milk synthesis and milk production during the last week prepartum. The mechanism that underlies the decrease in milk yield from a longer exposure to metabolic acidosis remains unclear, but it is possible that the 2 fewer days of gestation in cows fed long might have affected differentiation of the mammary epithelial cells into secretory cells and, in consequence, milk yield.

Another possibility is that longer exposure to metabolic acidosis might have influenced either prolactin signaling (Yang et al., 2013) or the growth hormone/ IGF-1 endocrine axis (Challa et al., 1993b) that is important to mammary development (Neville and Watters, 1983; Akers et al., 1990). In mouse cell culture systems transfected with human prolactin and growth hormone receptors, acidosis at $\mathrm{pH} 6.8$ disrupted prolactin receptor signaling (Yang et al., 2013). Those authors suggested that proton-induced disruption of prolactin signaling occurred by impeding ligand-receptor binding in tissues (Yang et al., 2013). Metabolic acidosis has been found to inhibit growth hormone secretion in rats (Challa et al., 1993b), and impair growth hormone/ IGF-1 endocrine axis function in humans (Challa et al., 1993a; Brüngger et al., 1997). Therefore, it is plausible to speculate that the prolonged metabolic acidosis for $42 \mathrm{~d}$ might have influenced mammogenesis either by influencing prolactin signaling in the mammary tissue

Table 7. Effects of level of DCAD and duration (DUR) of prepartum feeding on reproduction in Holstein cows ${ }^{1}$

\begin{tabular}{|c|c|c|c|c|c|c|c|}
\hline \multirow[b]{2}{*}{ Item $^{2}$} & \multicolumn{2}{|c|}{ Short } & \multicolumn{2}{|c|}{ Long } & \multicolumn{3}{|c|}{$P$-value ${ }^{3}$} \\
\hline & -70 & -180 & -70 & -180 & DUR & DCAD & $\begin{array}{l}\text { DUR } \times \\
\text { DCAD }\end{array}$ \\
\hline \multicolumn{7}{|l|}{ Pregnant, ${ }^{4} \%$ (no.) } & 0.33 \\
\hline First AI & $41.7(24)$ & $33.3(27)$ & $28.0(25)$ & $34.8(23)$ & 0.53 & 0.96 & 0.44 \\
\hline \multicolumn{8}{|l|}{ Days to pregnancy } \\
\hline $\mathrm{LSM} \pm \mathrm{SEM}$ & $150 \pm 14$ & $146 \pm 14$ & $174 \pm 16$ & $151 \pm 13$ & - & - & - \\
\hline Median (95\% CI) & $156(80-176)$ & $139(80-148)$ & $153(116-263)$ & $153(80-201)$ & - & - & - \\
\hline
\end{tabular}

${ }^{1}$ Cows were fed the following diets according to treatment: -70 short $=$ diet containing $+110 \mathrm{mEq} / \mathrm{kg}$ of DM from 232 to $254 \mathrm{~d}$ of gestation, followed by a diet with $-70 \mathrm{mEq} / \mathrm{kg}$ of DM from $255 \mathrm{~d}$ of gestation to calving; $-180 \_$short = diet containing $+110 \mathrm{mEq} / \mathrm{kg}$ of DM from 232 to $254 \mathrm{~d}$ of gestation, followed by a diet with $-180 \mathrm{mEq} / \mathrm{kg}$ of DM from $255 \mathrm{~d}$ of gestation to calving; $-70 \_$long = diet containing $-70 \mathrm{mEq} / \mathrm{kg}$ of DM from $232 \mathrm{~d}$ of gestation to calving; -180_long = diet containing $-180 \mathrm{mEq} / \mathrm{kg}$ of DM from $232 \mathrm{~d}$ of gestation to calving.

${ }^{2}$ Data collected for 305 d postpartum.

${ }^{3}$ DUR $=$ effect of feeding duration $(42$ vs. $21 \mathrm{~d}) ; \mathrm{DCAD}=$ effect of level of DCAD $(-70 \mathrm{vs} .-180) ; \mathrm{DUR} \times \mathrm{DCAD}=$ effect of interaction between DUR and DCAD (-70_short plus -180_long vs. -180_short plus -70_long).

${ }^{4}$ Pregnancy based on the diagnosis on d 67 after each AI according to the number of cows receiving at least 1 AI with pregnancy diagnosis performed.

${ }^{5}$ Pregnancy based on the diagnosis on d 67 according to the number of cows enrolled in the experiment. 

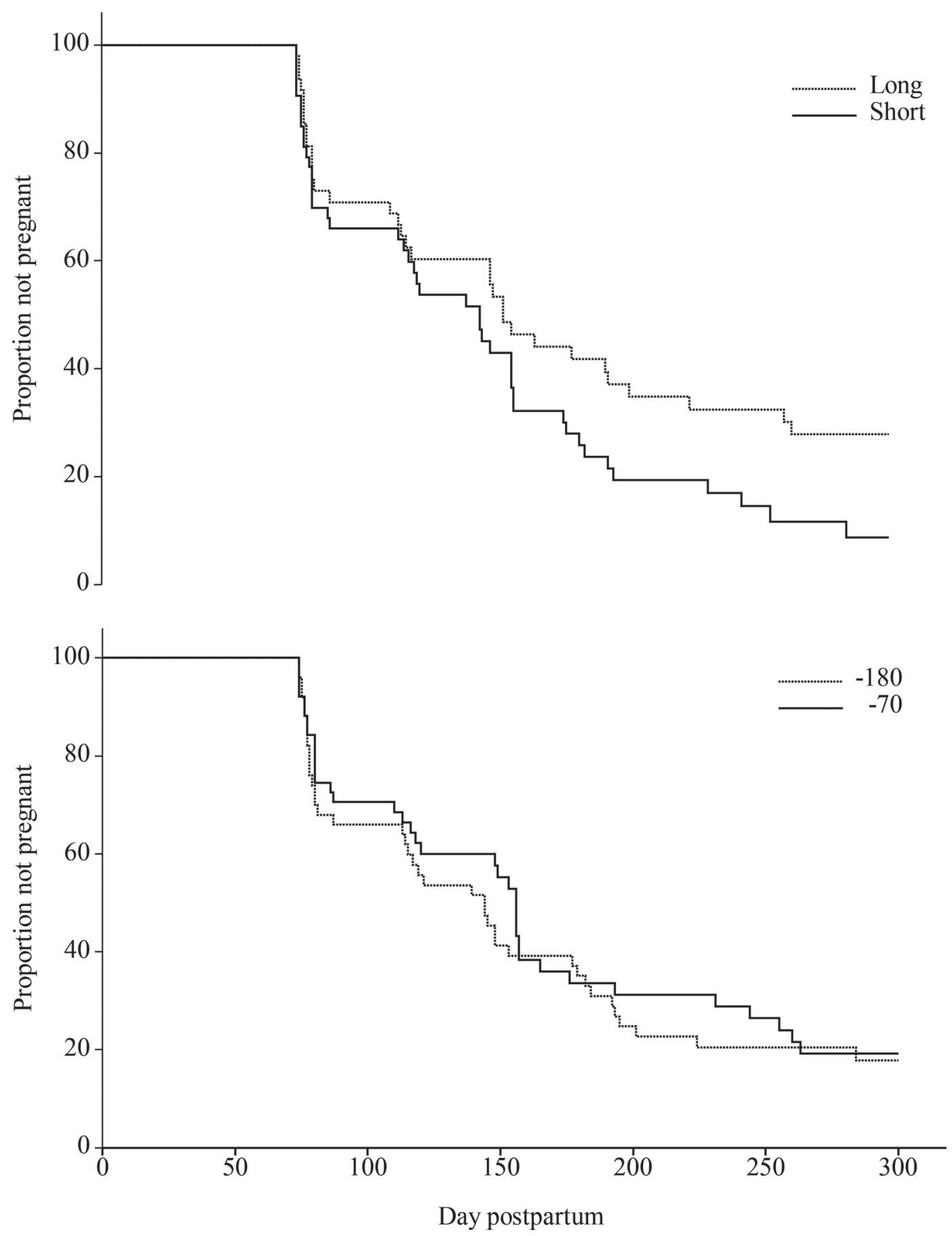

Figure 6. Survival curves for days from calving to pregnancy according to duration of prepartum feeding (short vs. long; A) and level of DCAD (-70 vs. $-180 \mathrm{mEq} / \mathrm{kg}$ of DM; B). (A) Median (95\% CI) and mean \pm SEM days to pregnancy were, respectively, 144 (113 to 156$)$ and $149 \pm 10 \mathrm{~d}$, resulting in $75.9 \%$ pregnant in cows fed short and 153 (114 to 201) and $168 \pm 11 \mathrm{~d}$ resulting in $60.0 \%$ pregnant in cows fed long. The adjusted hazard ratio (AHR) was $1.55(95 \% \mathrm{CI}=0.98$ to $2.45 ; P=0.06)$. (B) Median $(95 \% \mathrm{CI})$ and mean \pm SEM days to pregnancy were, respectively, 156 (116 to 165 ) and $162 \pm 11 \mathrm{~d}$ resulting in $64.9 \%$ pregnant in cows fed the diets with $-70 \mathrm{mEq} / \mathrm{kg}$ of $\mathrm{DM}$ and 144 (113 to 179 ) and $156 \pm 11 \mathrm{~d}$ resulting in $71.4 \%$ pregnant in cows fed the diets with $-180 \mathrm{mEq} / \mathrm{kg}$ of DM. The AHR was $0.89(95 \% \mathrm{CI}=0.57$ to $1.38 ; P=$ $0.59)$. Interaction between duration of feeding and level of DCAD did not affect time to pregnancy $(P=0.94)$.

or by reducing growth hormone/IGF-1 either directly or by the decreased DMI and the less-favorable nutrient balance.
Few experiments have evaluated the effect of level of DCAD on yield and composition of colostrum. Recently, Martinez et al. (2018) fed prepartum cows diets 
with approximately +130 or $-130 \mathrm{mEq} / \mathrm{kg}$ of $\mathrm{DM}$ and demonstrated that reducing the DCAD of prepartum diets did not influence colostrum yield or composition. Weich et al. (2013) showed that colostrum yield was unaffected by feeding acidogenic diets containing -150 $\mathrm{mEq} / \mathrm{kg}$ of $\mathrm{DM}$ either for the last 21 or $42 \mathrm{~d}$ of gestation. In the present experiment, reducing the DCAD from -70 to $-180 \mathrm{mEq} / \mathrm{kg}$ of DM reduced first milking colostrum yield by $1.4 \mathrm{~kg} / \mathrm{d}$, suggesting perhaps that a more severe metabolic acidosis with subsequent reduction in prepartum DMI might have effects on colostrum synthesis. Cows fed the $-180 \mathrm{mEq} / \mathrm{kg}$ of $\mathrm{DM}$ diet had measures of acid-base balance suggesting more severe metabolic acidosis than those of Weich et al. (2013) or those of Martinez et al. (2018), as reported by Rodney et al. (2018). Prepartum blood pH, base excess, and bicarbonate were all less in cows fed $-180 \mathrm{mEq} /$ $\mathrm{kg}$ of DM in the present experiment than those fed acidogenic diets reported by Rodney et al. (2018), and urinary $\mathrm{pH}$ in cows fed $-180 \mathrm{mEq} / \mathrm{kg}$ of $\mathrm{DM}$ was less than those reported by Rodney et al. (2018) or Weich et al. (2013). Therefore, it is possible that the more acidogenic diet fed in the current experiment induced a more pronounced metabolic acidosis that reduced nutrient intake which might have been detrimental to colostrum synthesis.

Although yield of first milking colostrum was depressed in cows fed -180 compared with $-70 \mathrm{mEq} / \mathrm{kg}$ of DM, the more acidogenic diet did not affect yields of milk or milk components in the first $42 \mathrm{~d}$ of lactation. Our results suggest that the negative effects of a more pronounced metabolic acidosis and subsequent reduced nutrient intake during late gestation are only present in the immediate postpartum, which reduces colostrum yield, but does not compromise subsequent lactation performance.

Acidogenic diets induce a typical compensated metabolic acidosis with a moderate decline in blood $\mathrm{pH}$, reduced blood bicarbonate and base excess, increased net acid urinary excretion, and reduced blood $\mathrm{pCO}_{2}$ (Vagnoni and Oetzel, 1998; Charbonneau et al., 2006). The decrease in blood $\mathrm{pH}$ from feeding diets with negative DCAD occurs because the increased absorption of strong anions, such as $\mathrm{Cl}^{-}$, leads to a loss of bicarbonate and an increase in free $\mathrm{H}^{+}$, which consequently reduces base excess and blood pH (Riond, 2001; Constable, 2014). This decrease in blood $\mathrm{pH}$ triggers a series of compensatory mechanisms, one of which is controlled by the respiration with increases in exhaled $\mathrm{CO}_{2}$, thereby reducing $\mathrm{tCO}_{2}$ concentrations in blood. Renal compensation also occurs with excess of acid excreted in the urine resulting in reduced urinary $\mathrm{pH}$, all of which were observed when cows were fed the diets with negative DCAD. Because cows fed the $-180 \mathrm{mEq} / \mathrm{kg}$ of
DM treatment received a more acidogenic diet, it was anticipated that their responses in acid-base balance would be more pronounced than those receiving the $-70 \mathrm{mEq} / \mathrm{kg}$ of $\mathrm{DM}$ diet.

Concentrations of iCa in blood prepartum and on the day of calving were greater in cows fed -180 than $-70 \mathrm{mEq} / \mathrm{kg}$ of DM, but these differences did not influence the risk of hypocalcemia. Two of 58 cows (3.5\%) fed short developed milk fever, and this incidence was less than values reported in the literature in herds with variable prepartum nutritional management (Lean et al., 2006; USDA, 2007; Reinhardt et al., 2011). It is well established that, as the prepartum DCAD decreases, blood iCa increases and risk of milk fever decreases (Charbonneau et al., 2006; Lean et al., 2006). Because all cows in the experiment were fed acidogenic diets prepartum, it is not surprising that incidence of milk fever was low, and risk of hypocalcemia did not differ among treatments. In fact, treatment did not affect the incidence of any of the individual diseases evaluated, morbidity, or multiple diseases. Hypocalcemia is known as a gateway disease and predisposes cows to other peripartum problems (Curtis et al., 1985; Martinez et al., 2012; Ribeiro et al., 2013). Lack of differences in hypocalcemia likely explains the absence of effects on morbidity.

Pregnancy per AI after all AI was greater for cows fed short than those fed long. The reduced P/AI resulted in a tendency for reduced pregnancy rate and extended days open. One possible explanation for the decreased reproductive performance of the cows fed long compared with those fed short is the longer exposure to the metabolic acidosis that reduced DMI during the dry period. The reduced nutrient intake caused a more negative NE balance prepartum. These cows also lost numerically more BW postpartum concurrent with less milk yield, perhaps suggesting that DMI was lower in early lactation in cows fed long than short. Because postpartum DMI was not measured, we can only speculate what might have happened with nutrient intake on that period. It is well characterized that reduced nutrient intake and more negative NE balance disrupts reproduction by delaying first postpartum ovulation and compromising P/AI (Staples et al., 1990). Wathes et al. (2007) proposed that the decreased reproductive performance in cows in more negative nutrient balance is in part linked to reduced systemic concentrations of IGF-1, which affects ovarian activity and early embryo development. Perhaps, the reduced nutrient intake observed during the dry period, when cows in long were fed acidogenic diets, might have also reflected in less intake postpartum, which could have affected subsequent reproductive performance. Another possibility is that cows fed acidogenic diets for $42 \mathrm{~d}$ had shorter gestation 
length, which has been associated with impaired reproductive performance (Norman et al., 2011; Vieira-Neto et al., 2017a). Even though the negative association between shorter duration of gestation and reduced reproductive performance has been shown, the underlying mechanism remains unclear. Finally, it is possible that prolonged acidosis for $42 \mathrm{~d}$ prepartum might have influenced tissue metabolism that has ramifications to reproduction in the subsequent lactation.

\section{CONCLUSIONS}

Feeding diets with negative DCAD induced a compensated metabolic acidosis in dairy cows regardless of the duration of feeding, but the acidosis was more severe in those fed the -180 than $-70 \mathrm{mEq} / \mathrm{kg}$ of DM. Cows fed the more acidogenic diet had increased iCa concentrations prepartum and at calving, but treatments did not influence morbidity or the incidence or daily prevalence of subclinical hypocalcemia. Reducing the DCAD decreased DMI, resulting in a more negative energy balance in the last weeks of gestation. Cows fed the more acidogenic diet yielded less colostrum, perhaps as consequence of less nutrient intake during the last weeks of gestation. Nevertheless, feeding the diet with $-180 \mathrm{mEq} / \mathrm{kg}$ of $\mathrm{DM}$ did not influence yields of milk, milk components, health, or reproduction in dairy cows compared with cows fed a diet with $-70 \mathrm{mEq} / \mathrm{kg}$ of DM, thereby suggesting that this range of DCAD is likely adequate for diets fed prepartum. Extending the duration of feeding diets with negative DCAD had minor effects on blood iCa and measures of acid-base status pre- and postpartum, but reduced milk yield in the first $42 \mathrm{~d}$ postpartum and $\mathrm{P} / \mathrm{AI}$ in all $\mathrm{AI}$ in the first $305 \mathrm{~d}$ of lactation. It is possible that the reduction in milk yield and reproductive performance caused by feeding acidogenic diets for $42 \mathrm{~d}$ prepartum might have a common underlying cause, although the current experiment does not allow us to identify it. Collectively, the present data suggest that feeding acidogenic diets beyond $21 \mathrm{~d}$ might be detrimental to dairy cows and there is no need to reduce the DCAD from -70 to $-180 \mathrm{mEq} / \mathrm{kg}$ of DM. Further experiments are needed to investigate the underlying mechanisms by which feeding acidogenic diets for $42 \mathrm{~d}$ influences production and reproduction in dairy cows.

\section{ACKNOWLEDGMENTS}

The authors thank Murilo R. Carvalho, Carolina Collazos, Diandra Lezier, Catalina Mejia, Paula Molinari, and Barbara Piffero from the University of Florida (Gainesville, FL) for their help with conduct- ing the experiment. We thank Sergei Sennikov from the University of Florida for assistance with analyses of samples. Financial support was provided by grants from the Southeast Milk Inc. Milk Check-off Program (Belleview, FL) and Arm \& Hammer Animal Nutrition (Princeton, NJ).

\section{REFERENCES}

Akers, R. M., W. E. Beal, T. B. Mcfadden, and A. V. Capuco. 1990. Morphometric analysis of involuting bovine mammary tissue after 21 or 42 days on non-suckling. J. Anim. Sci. 68:3604-3613.

Bigner, D. R., J. P. Goff, M. A. Faust, J. L. Burton, H. D. Tyler, and R. L. Horst. 1996. Acidosis effects on insulin response during glucose tolerance tests in Jersey cows. J. Dairy Sci. 79:2182-2188.

Block, E. 1984. Manipulating dietary anions and cations for prepartum dairy cows to reduce incidence of milk fever. J. Dairy Sci. 67:2939-2948.

Box, G., and D. Cox. 1964. An analysis of transformations. J. Royal Stat. Soc. B (Methodological) 26:211-252.

Brüngger, M., H. N. Hulter, and R. Krapf. 1997. Effect of chronic metabolic acidosis on the growth hormone/IGF-1 endocrine axis: New cause of growth hormone insensitivity in humans. Kidney Int. $51: 216-221$.

Capuco, A. V., R. M. Akers, and J. J. Smith. 1997. Mammary growth in Holstein cows during the dry period: Quantification of nucleic acids and histology. J. Dairy Sci. 80:477-487.

Challa, A., W. Chan, R. J. Krieg, M. A. Thabet, F. Liu, R. L. Hintz, and J. C. Chan. 1993a. Effect of metabolic acidosis on the expression of insulin-like growth factor and growth hormone receptor. Kidney Int. 44:1224-1227.

Challa, A., R. J. Krieg, M. A. Thabet, J. D. Veldhuis, and J. C. Chan. 1993b. Metabolic acidosis inhibits growth hormone secretion in rats: mechanism of growth retardation. Am. J. Physiol. 265:E547-E553.

Charbonneau, E., D. Pellerin, and G. R. Oetzel. 2006. Impact of lowering dietary cation-anion difference in nonlactating dairy cows: A meta-analysis. J. Dairy Sci. 89:537-548.

CLSI. 2001. Blood Gas and pH Analysis and Related Measurements; Approved Guideline. Clinical and Laboratory Standards Institute document C46-A. CLSI, Wayne, PA.

Constable, P. D. 2014. Acid-base assessment: When and how to apply the Henderson-Hasselbalch equation and strong ion difference theory. Vet. Clin. North Am. Food Anim. Pract. 30:295-316.

Curtis, C. R., H. N. Erb, C. J. Sniffen, R. D. Smith, and D. S. Kronfeld. 1985. Path analysis of dry period nutrition, postpartum metabolic and reproductive disorders, and mastitis in Holstein cows. J. Dairy Sci. 68:2347-2360.

Degaris, P. J., I. J. Lean, A. R. Rabiee, and C. Heuer. 2008. Effects of increasing days of exposure to prepartum transition diets on milk production and milk composition in dairy cows. Aust. Vet. J. 86:341-351.

Elanco Animal Health. 2009. The 5-point body condition scoring system. Bulletin AI 10752. Elanco Animal Health, Greenfield, IN.

Ender, F., I. Dishington, and A. Helgebostad. 1971. Calcium balance studies in dairy cows under experimental induction and prevention of hypocalcaemic paresis puerperalis. Z. Tierphysiol. Tierernahr. Futtermittelkd. 28:233-256.

Ferguson, J. D., D. T. Galligan, and N. Thomsen. 1994. Principal descriptors of body condition score in Holstein cows. J. Dairy Sci. 77:2695-2703.

Gochman, N., and J. M. Schmitz. 1972. Application of a new peroxide indicator reaction to the specific, automated determination of glucose with glucose oxidase. Clin. Chem. 18:943-950.

Horst, R. L., J. P. Goff, and T. A. Reinhardt. 2005. Adapting to the transition between gestation and lactation: Differences between rat, human and dairy cow. J. Mammary Gland Biol. Neoplasia 10:141-156. 
Johnson, M. M., and J. P. Peters. 1993. Technical note: An improved method to quantify nonesterified fatty acids in bovine plasma. J. Anim. Sci. 71:753-756.

Jørgensen, E., and A. R. Pedersen. 1998. How to obtain those nasty standard errors from transformed data - and why they should not be used. Biometry Research Unit - Internal report 7. Danish Institute of Agricultural Sciences, Tjele, Denmark. http://gbi.agrsci .dk/ ejo/publications/dinapig/intrep7.pdf.

Lean, I. J., P. J. DeGaris, A. R. Rabiee, and E. Block. 2006. Hypocalcemia in dairy cows: Meta-analysis and dietary cation anion difference theory revisited. J. Dairy Sci. 89:669-684.

Leno, B. M., C. M. Ryan, T. Stokol, D. Kirk, K. P. Zanzalari, J. D. Chapman, and T. R. Overton. 2017. Effects of prepartum dietary cation-anion difference on aspects of peripartum mineral and energy metabolism and performance of multiparous Holstein cows. J. Dairy Sci. 100:4604-4622.

Martinez, N., C. A. Risco, F. S. Lima, R. S. Bisinotto, L. F. Greco, E. S. Ribeiro, F. Maunsell, K. Galvão, and J. E. P. Santos. 2012. Evaluation of peripartal calcium status, energetic profile, and neutrophil function in dairy cows at low or high risk of developing uterine disease. J. Dairy Sci. 95:7158-7172.

Martinez, N., R. M. Rodney, E. Block, L. L. Hernandez, C. D. Nelson, I. J. Lean, and J. E. P. Santos. 2018. Effects of prepartum dietary cation-anion difference and source of vitamin D in dairy cows: Lactation performance and energy metabolism. J. Dairy Sci. 101:2544-2562.

Martinez, N., L. D. P. Sinedino, R. S. Bisinotto, R. Daetz, C. A. Risco, K. N. Galvão, W. W. Thatcher, and J. E. P. Santos. 2016. Effects of oral calcium supplementation on productive and reproductive performance in Holstein cows. J. Dairy Sci. 99:8417-8430.

Neville, M. C., and C. D. Watters. 1983. Secretion of calcium into milk. J. Dairy Sci. 66:371-380. (Review).

Norman, H. D., J. R. Wright, and R. H. Miller. 2011. Potential consequences of selection to change gestation length on performance of Holstein cows. J. Dairy Sci. 94:1005-1010.

NRC. 2001. Nutrient Requirements of Dairy Cattle. 7th rev. ed. Natl. Acad. Press, Washington, DC.

Oetzel, G. R. 1988. Parturient paresis and hypocalcemia in ruminant livestock. Vet. Clin. North Am. Food Anim. Pract. 4:351-364.

Quinlan, K., and M. DeSesa. 1955. Spectrophotometric determination of phosphorus as molybdiphosphoric acid. Anal. Chem. 20:749 751 .

Reinhardt, T. A., J. D. Lippolis, B. J. McCluskey, J. P. Goff, and R. L. Horst. 2011. Prevalence of subclinical hypocalcemia in dairy herds. Vet. J. 188:122-124.

Ribeiro, E. S., F. S. Lima, L. F. Greco, R. S. Bisinotto, A. P. A. Monteiro, M. Favoreto, H. Ayres, R. S. Marsola, N. Martinez, W. W. Thatcher, and J. E. P. Santos. 2013. Prevalence of periparturient diseases and effects on fertility of seasonally calving grazing dairy cows supplemented with concentrates. J. Dairy Sci. 96:5682-5697.

Riond, J. L. 2001. Animal nutrition and acid-base balance. Eur. J. Nutr. 40:245-254.

Rodney, R. M., N. Martinez, E. Block, L. L. Hernandez, P. Celi, C. D. Nelson, J. E. P. Santos, and I. J. Lean. 2018. Effects of prepartum dietary cation-anion difference and source of vitamin D in dairy cows: Vitamin D, mineral, and bone metabolism. J. Dairy Sci. 101:2519-2543.

Schirmann, K., N. Chapinal, D. M. Weary, W. Heuwieser, and M. A. von Keyserlingk. 2011. Short-term effects of regrouping on behavior of prepartum dairy cows. J. Dairy Sci. 94:2312-2319.

Souza, A. H., H. Ayres, R. M. Ferreira, and M. C. Wiltbank. 2008. A new presynchronization system (Double-Ovsynch) increases fertility at first postpartum timed AI in lactating dairy cows. Theriogenology 70:208-215.

St-Pierre, N., and W. P. Weiss. 2017. Variability in feed sampling and analyses. Pages 713-722 in Large Dairy Herd Management. 3rd ed. D. K. Beede, ed. ADSA, Champaign, IL.
Staples, C. R., W. W. Thatcher, and J. H. Clark. 1990. Relationship between ovarian activity and energy status during the early postpartum period of high producing dairy cows. J. Dairy Sci. 73:938-947.

Stone, W. C., and S. A. Mosley. 2017. Nutritional diagnostic troubleshooting. Pages $771-786$ in Large Dairy Herd Management. 3rd ed. D. K. Beede, ed. ADSA, Champaign, IL.

Sukhija, P. S., and D. L. Palmquist. 1988. Rapid method for determination of total fatty acid content and composition of feedstuffs and feces. J. Agric. Food Chem. 36:1202-1206.

USDA. 2007. Dairy 2007. Part I: Reference of dairy cattle health and management practices in the United States. https://www .aphis.usda.gov/animal_health/nahms/dairy/downloads/dairy07/ Dairy07_dr_PartI.pdf.

USDA. 2008. Dairy 2007, Part III: Reference of dairy cattle health and management practices in the United States. https://www .aphis.usda.gov/animal_health/nahms/dairy/downloads/dairy07/ Dairy07_dr_PartIII_rev.pdf.

USDA. 2016. Dairy 2014, dairy cattle management practices in the United States. https://www.aphis.usda.gov/animal_health/ nahms/dairy/downloads/dairy14/Dairy14_dr_PartI.pdf.

Vagnoni, D. B., and G. R. Oetzel. 1998. Effects of dietary cationanion difference on the acid-base status of dry cows. J. Dairy Sci. 81:1643-1652.

Valadares, R. F. D., G. A. Broderick, S. C. Valadares Filho, and M. K. Clayton. 1999. Effect of replacing alfalfa silage with high moisture corn on ruminal protein synthesis estimated from excretion of total purine derivatives. J. Dairy Sci. 82:2686-2696.

Van Soest, P. J., J. B. Robertson, and B. A. Lewis. 1991. Methods for dietary fiber, neutral detergent fiber and nonstarch polysaccharides in relation to animal nutrition. J. Dairy Sci. 74:3583-3597.

Vidal, B. C., Jr., K. D. Rausch, M. E. Tumbleson, and V. Singh. 2009. Determining corn germ and pericarp residual starch by acid hydrolysis. Cereal Chem. 86:133-135.

Vieira-Neto, A., K. N. Galvão, W. W. Thatcher, and J. E. P. Santos. 2017a. Association among gestation length and health, production, and reproduction in Holstein cows and implications for their offspring. J. Dairy Sci. 100:3166-3181.

Vieira-Neto, A., I. R. P. Lima, F. Lopes Jr., C. Lopera, R. Zimpel, L. D. P. Sinedino, K. C. Jeong, K. N. Galvão, W. W. Thatcher, C. D. Nelson, and J. E. P. Santos. 2017b. Use of calcitriol to maintain postpartum blood calcium and improve immune function in dairy cows. J. Dairy Sci. 100:5805-5823.

Wathes, D. C., M. Fenwick, Z. Cheng, N. Bourne, S. Llewellyn, D. G. Morris, D. Kenny, J. Murphy, and R. Fitzpatrick. 2007. Influence of negative energy balance on cyclicity and fertility in the high producing dairy cow. Theriogenology 68:S232-241.

Weich, W., E. Block, and N. B. Litherland. 2013. Extended negative dietary cation-anion difference feeding does not negatively affect postpartum performance of multiparous dairy cows. J. Dairy Sci. 96:5780-5792.

Wu, Z., J. K. Bernard, K. P. Zanzalari, and J. D. Chapman. 2014 Effect of feeding a negative dietary cation-anion difference diet for an extended time prepartum on postpartum serum and urine metabolites and performance. J. Dairy Sci. 97:7133-7143.

Yang, N., C. Liu, A. R. Peck, M. A. Girondo, A. F. Yanac, T. H. Tran, F. E. Utama, T. Tanaka, B. Freydin, I. Chervoneva, T. Hyslop, A. J. Kovatich, J. A. Hooke, C. D. Shriver, and H. Rui. 2013. Prolactin-Stat5 signaling in breast cancer is potently disrupted by acidosis within the tumor microenvironment. Breast Cancer Res. 15:R73.

Zimpel, R., M. B. Poindexter, A. Vieira-Neto, E. Block, C. D. Nelson, C. R. Staples, W. W. Thatcher, and J. E. P. Santos. 2018. Effect of dietary cation-anion difference on acid-base status and dry matter intake in dry pregnant cows. J. Dairy Sci. 101. https://doi.org/10 .3168/jds.2018-14748. 